\title{
Organizational and Ideological Strategies for Nationalization: Evidence from European Parties
}




\begin{abstract}
How does a party's organizational structure affect its chances of becoming a national party? While existing explanations of party nationalization focus on countrylevel institutional and societal variables, we argue that aspects of party organization such as the degree of centralization of authority, ideological unity and leadership factionalism also matter. By bringing the analysis to the party level, this article provides a multilevel analysis of institutional and party organization variables and disentangles the effect of each set of influences. We use original data on party organization and party nationalization for 142 parties across 20 European countries. This research contributes to the literature on nationalization and party development by advancing organizational strategies which parties could adopt in different social and institutional environments.
\end{abstract}


Throughout the 19th and 20th centuries, European electorates and parties have become increasingly nationalized due to a parallel process of modernization and democratization (Caramani, 2004). Yet despite this nationalizing trend, significant variation in nationalization remains both across and within countries in Europe today. The goal of this article is to explain this variation by focusing on the role of parties' organizational and ideological strategies.

Understanding why parties are more or less nationalized in a country is important for two reasons. First, the local or national character of parties influences the nature of policies produced in a country (Jones and Mainwaring, 2003). According to Hicken (2009) and Rodden (2010) when political competition occurs between parties that represent specific sub-national constituencies there tends to be an oversupply of pork-barrel policies and an undersupply of nationally-focused public goods. In contrast, parties that have national programmatic appeals and national electorates are more likely to enact progressive redistributive policies. Second, the local or national character of parties may affect demands for secession and levels of violent conflict within a country (Bakke and Wibbels, 2006; Brancati, 2009). As Rose and Urwin (1975) note "geographically narrow parties are frequently accompanied by separatist goals, whereas parties with broad geographic support will tend to have an integrating impact on the state and thus provide for a level of political stability that would be absent without their presence" (Morgenstern, Swindle and Castagnola, 2009, 1323-1324).

Existing literature attributes cross-country variation in party system nationalization to a variety of socio-structural and institutional explanations such as a state's centralization of authority (Chhibber and Kollman, 2004, 1998) and the concentration of that authority at the national level (Hicken, 2009). The concurrency of legislative and presidential elections or the number of presidential candidates (Hicken and Stoll, 2013; Amorim Neto and Cox, 1997; Cox and McCubbins, 1999) also has an impact on nationalization and similarly do the presence of territorial and ethno-cultural cleavages (Lipset and Rokkan, 1967; Cox and McCubbins, 1999; Caramani, 2004). Yet despite the important inroads which explain cross-national differences in party systems, we know very little about why parties within the same country and the same institutional and societal context have different degrees of nationalization.

This article explores this within country-variation by focusing on how parties' internal organization affects their likelihood of spreading nationally. The argument is as follows. We posit that from a party's perspective becoming national has both benefits and costs. The benefits are the increased chances of attaining office at the 
national level, while the costs relate to the difficulty of building a party organization that has the resources, experience and ability to lure both candidates and voters from a variety of different electoral constituencies. We argue that some parties are more successful than others at solving this coordination problem. Drawing from rational models of organization theory (Hatch, 1997; Mintzberg, 1990, 101), we argue that in order to nationalize parties need strategies or large scale plans for developing and competing in elections and good tactics to adjust to competitive situations. The strategy involves managing the organization's relationship with its environment which takes the form of electors, electoral rules and party rivals. The tactics employed within this strategy refer to how organizational resources such as finance, members, infrastructure will be developed, acquired and used in order to achieve the goal of nationalization.

In particular, we posit that the way in which a party is internally organized in terms of centralization of authority, leadership factionalism, and heterogeneity of their ideological platform matter for explaining their success in nationalizing. Parties with centralized decision-making authority and absence of leadership factionalism should be better able to spread nationally because they can overcome the organizational and collective action challenges of presenting candidates everywhere. This effect should be particularly strong in federal or decentralized countries where the collective action problems are particularly challenging. We also argue that ideologically diverse parties are more likely to be nationalized because ideological flexibility helps parties cater to a (potentially) diverse set of electoral constituencies and lure voters across the territory. Ideological diversity is particularly important when local interests in a country are salient, that is when preferences are geographically concentrated and when the electoral system promotes local (instead of national) interests.

We advance and test our claims with an original dataset that combines partylevel and country-level variables. The dataset contains measures of various aspects of party organization for 142 parties in 20 European countries based on an expert survey. Our analysis is unique because extensive comparative data on party organization is scarce. Some studies are comparative but not very recent (Janda, 1980) whereas most recent studies are detailed country studies, qualitative comparisons or regional quantitative comparisons (Boucek, 2003, 2012; Schumacher, de Vries and Vis, 2013; Tavits, 2011). Furthermore, most research focuses on just one aspect of party organization (usually party centralization or party organizational strength) whereas we are able to study the impact of different aspects of party organization such as the concentration of decision making (centralization), programmatic 
cohesion (ideological unity) and internal divisions (leadership factionalism). ${ }^{1}$ We therefore focus on "formal" and relatively stable organizational features such as centralization as well as on more transient organizational features such as leadership factionalism and ideological unity, which are more likely to change over time. The last two features are a reflection of party coherence (Janda, 1980, 118) understood as "the degree of congruence in the attitudes [ideological unity] and behaviour [factionalism] of party members." We consider ideological unity both as an ideological and an organizational characteristic of parties as it relates to the ideological congruence of party members and representatives. Our dataset also contains measures of party nationalization for each of the 142 parties in the dataset as well as various country-level societal and institutional variables.

This article contributes to the literature on parties empirically through this new dataset, and theoretically, by placing emphasis on party organization as a key explanatory variable. For quite some time studies of parties and party systems have neglected the role of party organization, ${ }^{2}$ but recent studies suggest that it might be an important dimension to understand a variety of political outcomes such as electoral success (Janda and Colman, 1998; Tavits, 2011; Greene and Haber, 2015; Ishiyama, 2001), changes in party policy position (Schumacher, de Vries and Vis, 2013) and the number of parties in a party system (Chhibber and Suryanarayan, 2014). ${ }^{3}$ Within this recent research agenda, this article is the first to investigate how party organization affects the territorial nature of parties' electoral support. It is also one of the few studies that looks at how party-level factors interact with social and institutional variables in explaining political outcomes. Finally, the article contributes to the literature on nationalization by bringing the analysis down to the party-level and addressing previously unexplained within-country variation.

\footnotetext{
${ }^{1}$ The Political Parties Database Project is another ongoing data collection project based on official documents such as party statutes which will contribute to providing more fine-grained comparative data on party organization. See Scarrow and Webb (2013) for a description of the project.

${ }^{2}$ There are some notable exceptions such as the work of Janda who wrote widely on party organization and its effects on party performance (Janda and Colman, 1998).

${ }^{3}$ Kernell (2013) has written on party organization and political participation and Meguid (2008) explores how party organization explains decisions to decentralize the state among mainstream parties in the UK. Other scholars consider individual aspects of organization (Rahat, Reuven and Katz, 2008; Janda and King, 1985; Rahat, 2009; Rahat and Hazan, 2001; Norris, 1996; Hazan, 2002) such as decision making and candidate selection or democratic centralism which increases the probability of a party split (Ceron, 2015).
} 


\section{Conquering Space: Argument and Hypotheses}

Why do individual candidates competing in their own district decide to coordinate across districts to form a broad nation-wide party? According to several scholars the answer to this question has to do with the incentives associated with gaining control of the central government (Cox and Knoll, 2003; Cox and McCubbins, 1999; Hicken, 2009). Regardless of whether individual candidates (or local parties) are office seeking or policy-seeking becoming national has obvious rewards since it increases the chances that such a party will gain representation at the national level and that the candidates within the party will have access to the power and resources associated with office, and the ability to influence policy. Yet, despite these incentives, not all political parties are fully nationalized.

Figure 1 presents the variation in party nationalization for 142 parties in 20 European countries. Each boxplot represents the distribution of parties' nationalization scores for the election year 2007 (or the closest national election after that year). Higher values of party nationalization (y-axis) indicate that a party's vote share is equally distributed across constituencies in a country; lower values indicate that a party's vote share comes mostly from one (or a few constituencies) and thus its support is territorialized). ${ }^{4}$ The boxplots suggests that there is considerable variation in the extent to which parties are nationalized within countries (as well as across countries). With the exception of Sweden (where all parties are national in scope), European parties in our dataset have very different degrees of nationalization.

We posit that not all parties are national because despite the considerable benefits associated with the decision to form a national party, there are also significant costs which not all parties are ready to overcome with an adequate strategy. Becoming national -that is "conquering space" ${ }^{5}$-requires overcoming two challenges. The first challenge is organizational. Developing a national party requires individual candidates to construct an organization with sufficient resources, experience and coherent decision-making to present their own candidates in the rest of districts in the country and/or to lure candidates from other districts to compete under their party label. This presents a collective action problem, which is akin to the one Aldrich (1995) identifies in the creation of "the first national, mass-based party in history" [97] - the Democratic party. According to Aldrich (1995), Van Buren's main challenge in trying to revive the Democratic party was "securing the participation of other elective office seekers, office holders, and benefit seekers who commanded the extensive resources necessary to join his plan and create this new Democratic party"

\footnotetext{
${ }^{4}$ Details on the measurement of this variable are provided in subsequent sections.

${ }^{5}$ The term "conquering space" is taken from Caramani (2004).
} 
Figure 1: Party Nationalization Across and Within Countries

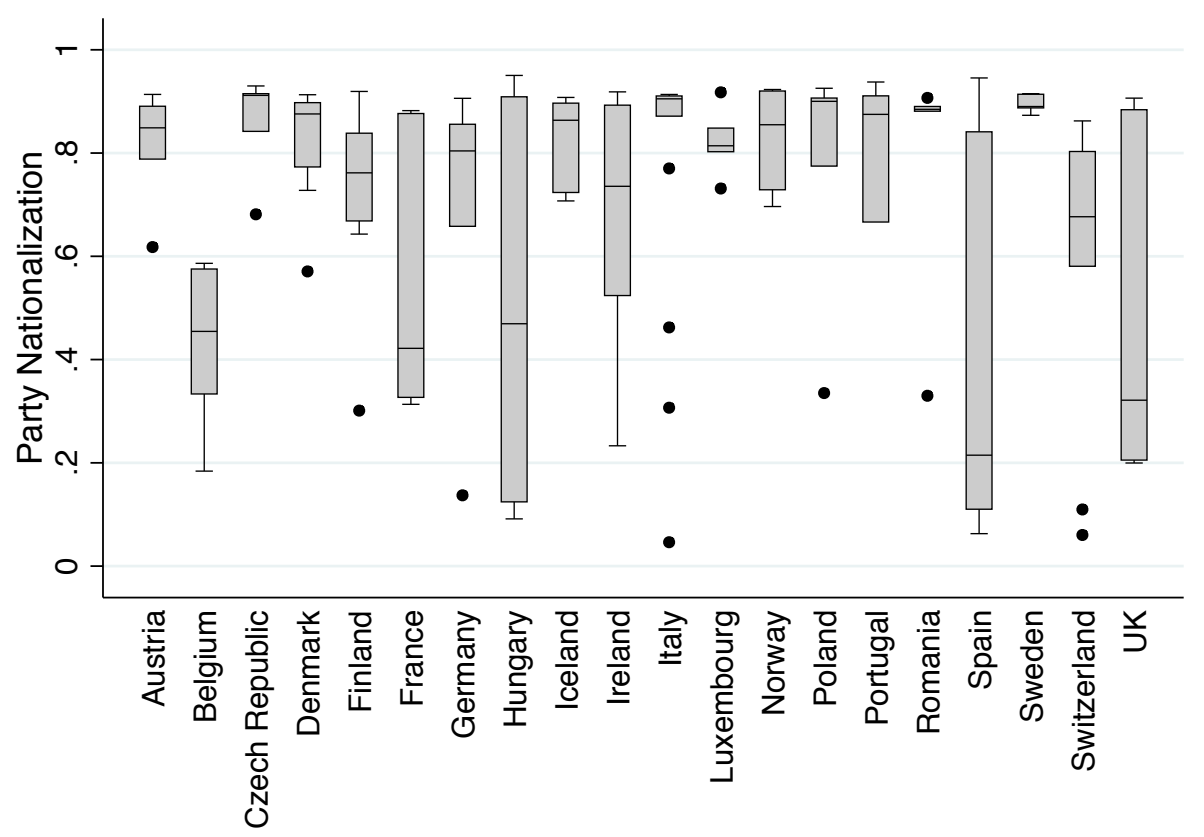

[104]. In other words, successful nation-wide parties require a broad based organization with substantial resources and enough candidates to field in every electoral district.

The second challenge is electoral. To become a national party it is not sufficient to build a nation-wide organization that has the resources to present candidates everywhere; the party also needs to be able to win everywhere. In other words, a successful national party is one that obtains a relatively even electoral support across all districts in the country. This is challenging from an ideological point of view since preferences across districts can be potentially very diverse.

Our argument focuses on party strategies as a response to these two challenges of nationalization. We argue that the way in which a party is internally organized with regards to the extent of centralization, leadership factionalism, and ideological heterogeneity has an impact on the resolution of these challenges and thus on the likelihood that a party will become nationalized with regards to its electoral support. Specifically, we try to isolate the effect of organization on party nationalization. We do not exclude the possibility of a dynamic relationship between these two sets of variables across time but in this paper we focus mainly on one causal line from party organization to party nationalization. Furthermore, we argue that parties do not operate in a social and institutional vacuum but rather respond to their 
environment. Henceforth we posit that these party organization variables interact with several contextual factors to explain success in nationalizing. The "strategic fit" (Hatch, 1997) in order to achieve nationalization is therefore the successful party strategy which aligns the needs and demands of the institutional and electoral environment with those of the party organization. In what follows we develop our hypotheses.

\section{Centralization of authority}

Organization theory stipulates that "control of others offers organizations predictability which is necessary to produce outputs and to coordinate actions "(CzaniawskaJoerges, 1988, 2-3). Similarly, for parties, strong decision-making from the centre helps them develop and better coordinate campaigns in order to be successful across constituencies. According to Duverger, highly centralized parties tend to be more successful in mobilizing votes, which explains the "superiority of 'modern' massmembership organizations, adopted by leftist parties, over the loose caucus-type organizations of older, more conservative parties" (Janda and Colman, 1998, 620621). Furthermore, Duverger connects party centralization not only to electoral success but also to nationalization, although he does not fully explain the mechanisms of this connection: "the increased centralization of organization within the parties and the consequent tendency to see political problems from the wider, national standpoint tend of themselves to project on to the entire country the localized two-party system brought about by the ballot procedure" (Duverger, 1954, 228).

We posit that centralization of authority within the party leads to nationalization because party leaders are the ones most interested in attaining office at the national level, and nationalizing is a means to achieve national office. Recent research argues that party leaders in leadership-dominated parties (i.e. centralized parties) are more oriented towards political office (and reaping the benefits of that office); whereas party leaders in activist dominated parties (i.e. decentralized parties) tend to be more responsive to activists and less worried about office (Schumacher, de Vries and Vis, 2013, 2). Similarly, Strom (1990) states that the more decentralized the party is in its decision-making, the "more policy-oriented the party becomes at the expense of office or vote seeking" [577]. If this is the case, in centralized parties it is more likely that the preferences of national party leaders will be implemented, which means it is more likely to expect a strategy of spreading nationally, in order to subsequently reap the benefits of national office. In contrast, a decentralized decision-making process opens the door to preferences of activists and rank-andfile party members, which are less interested in national public office and more 
interested in policy. This leads to the following hypothesis: ${ }^{6}$

H1. Centralization of authority within a party increases the likelihood that the party will be nationalized.

\section{Leadership Factionalism}

The other organizational feature which can help a party overcome the electoral and organizational challenge is unity around party leadership. Consensus and support for the party leader exercises influence over members and can influence their behaviour which subsequently helps party coordination across districts. There are various types of factionalism - leadership, issue, ideological (c.f. Janda 1980) amongst which we consider leadership factionalism to be detrimental to party nationalization because its presence can increase a party's coordination costs across constituencies. Compared with centralization which is a more formal and stems from procedures outlined in the party documents, leadership factionalism is a more transient organizational feature and relates more to the personality of the leader. Existing research suggests that voters tend to go for the party label that portrays itself as a united bloc, and divisions of leadership, lack of concentration of power and disunity can bring electoral defeat (Schattschneider, 1942; McGann, 2002; Snyder and Ting, 2002). Consequently voters negatively associate factionalism with parties' ability to translate programmes into coherent policy (Boucek, 2003; McAllister, 1991) (Katz, 1980, 3) (Kitschelt et al., 1999, 136-137). We argue that leadership factionalism also matters for nationalization (and not only for electoral success) because it makes it hard for a party to agree on a coherent and expensive nation-wide strategy that involves recruiting and presenting candidates in every electoral district. As Meguid (2008) argues elite factionalism within parties reduces a "party's ability to choose electorally costly or resource-intensive strategies" [105]. As argued earlier, garnering support from a variety of co-partisan and fielding candidates everywhere is a costly activity for the party, and some of its leaders might not want to incur such costs. We thus expect leadership factionalism to discourage nationalization.

\footnotetext{
${ }^{6}$ Some scholars have argued that party organizational strength (which is somewhat linked to party centralization) might be associated with poor electoral performance. Tavits (2011) reviews these counterarguments explaining that "an extensive organization introduces strategic inflexibility (Levitsky 2003), which may lead to party stagnation and loss of electoral support. Large organizations may become inefficient and wasteful; they may put the party in a financial strain rather than helping keep down costs (Scarrow, 1994)" (Tavits, 2011, 86). These arguments are concerned with electoral success, although one might imagine that centralization could also potentially undermine nationalization due to similar reasons of inflexibility and over-bureaucratization. We discuss this further in the results section.
} 
H2. Leadership factionalism within a party decreases the likelihood that a party will be nationalized.

Furthermore, we expect that the negative effect of leadership factionalism will be strongest in countries that are federal (or very decentralized) since in these countries faction leaders are usually tied to territorial/regional constituencies where the incentives to implement autonomous policy agendas rather than the national party agenda are high (Leon, 2014; Golosov, 2016). In this context, leaders representing certain constituencies and regions might not agree with a strategy of nationalization, which would hinder its success. In contrast, in unitary countries, leadership factionalism should not matter as much for coordinating across the territory since competing leaders are not necessarily as tied to regional power bases. We thus expect the following interactive hypothesis:

H3. Leadership factionalism $x$ Political Decentralization: The negative impact of leadership factionalism on party nationalization is larger in decentralized countries.

In sum, leadership factionalism and low levels of centralization of authority should constrain a party's strategy to spread nationally. In contrast, parties with a centralized decision-making structure and a unified leadership should give priority to the interest of nationalization and should allow this decision to be implemented.

\section{Ideological Unity}

Political parties vary considerably in the degree to which their party platform is ideologically cohesive. Parties are collective actors (Duverger, 1954; Sartori, 1976; Katz, 1980) and this introduces the possibility of intra-party differences and intra-party conflict, which can be reflected in how the party presents itself ideologically to the voters. Existing literature on parties has argued that ideological unity (or its converse, ideological heterogeneity) affects a variety of aspects of legislative behaviour such as agenda setting (Cox and McCubbins, 2005) and policy outputs (Tsebelis, 2002). In addition to this, we argue that ideological heterogeneity helps parties nationalize. Autonomy in organizations involves a much needed degree of "flexibility and creativity which is essential for adaptation to changing environments" (Czaniawska-Joerges, 1988, 2-3). Following this logic, we argue that the extent of flexibility with regards to ideological platform determines how well a party can respond to both the electoral and organizational challenge of nationalization.

The catch-all literature (Hale Williams, 1009; Kirchheimer, 1966; Forestiere, 2009; Kirchheimer, 2008) has posited that in order to get more votes, parties follow 
a strategy of centering and widening rather than tightening their ideological profile. We posit that a similar logic of ideological competition is at play when parties try to spread nationally; in Caramani (2004)'s terminology, in order to become "catchall-over parties" (i.e. national parties) parties need to be "catch-all" and appeal to a potentially very diverse set of interests across constituencies. We hypothesize that greater ideological heterogeneity within the party should allow greater adaptability to diverse local conditions and to a potentially diverse set of interests. The more a party can respond to diverse ideological views across the territory the better positioned it will be to win votes across districts and thus to expand nationally. In contrast, ideological unity should make it harder for parties to appeal to a broad range of interests across electoral constituencies and to obtain nation-wide support. We thus expect the following:

H4. Ideological unity within the party decreases the likelihood that a party will be nationalized.

We think that ideological unity can have different effects in different arenas. Our argument regarding ideological unity pertains mainly to party strategies in the electoral arena as we posit that ideological heterogeneity might help parties garner electoral support across the territory. However, we acknowledge that ideological unity rather than ideological heterogeneity may be needed in the parliamentary arena in order to generate high unity in roll-call votes which in turn may increase a party's electoral success and perhaps also further its chances for nationalization. This would run against the effect of ideological unity in the electoral arena (at least regarding party nationalization). This possibility does not invalidate our argument, which is mostly concerned about parties' organizational strategies in the electoral arena, but it shows that parties are constantly faced with difficult trade-offs, and strategies that might work well in certain arenas to attain certain goals (i.e. nationalization) might not work in other arenas to obtain that same goal. The party is thus faced with difficult choices. ${ }^{7}$

If the mechanisms of our argument regarding party nationalization are correct, then we should expect the extent of ideological unity to matter especially when local interests in a country are more salient since that is when parties need programmatic or ideological flexibility. Several factors in a country have the potential to localize politics and contribute to the saliency of local interests and we focus on two such factors: geographically concentrated diversity and an electoral system that encourages a personal vote.

\footnotetext{
${ }^{7}$ We thank an anonymous reviewer for pointing out these contradictory effects of ideological unity depending on which arena (and which goals) the party is focused on.
} 
Regarding the first factor, we expect the ideological make-up of the party to matter most in this context of geographically concentrated socio-economic diversity. If the party is ideologically heterogeneous it will be able to adopt differentiated electoral platforms in order to win seats across the territory. By contrast, if the party is ideologically unified in a context of concentrated diversity we expect it to do poorly in some constituencies and thus its electoral support will be territorialized. As socioeconomic diversity becomes less and less geographically concentrated, the effect of having an ideologically united party versus an ideologically diverse party should be smaller or non-existent, since constituencies will have similar policy preferences. This leads to the following interactive hypothesis:

H5. Ideological Unity $x$ Concentrated Diversity: The negative effect of ideological unity on party nationalization is larger when diversity in a country is territorially concentrated.

In addition to a country's societal make-up, we posit that electoral institutions also territorialize or localize interests in a polity. As Carey and Shugart (1995) argue, single member districts favour intra-party conflict and personalized politics, which will deflect attention from a national message to a constituency message and increase personal rivalries amongst candidates. Because this article is focused on European political parties, there are very few countries with single-member districts. Within proportional and mixed electoral systems however there is still significant variation in the personalization of the vote and of candidates. In order to capture such variation we focus on two variables related to the electoral system: district magnitude and number of districts. Countries with low district magnitude and large number of districts are likely to have more localized interests.

We thus argue that the negative impact of ideological unity on party nationalization should be minimal (or disappear) when district magnitude is large and when there are few districts since in these cases inter-district differences are smaller and interests tend to be more nationally oriented (i.e. local issues are less important). In contrast, the negative impact of ideological unity on party nationalization should be particularly strong when the electoral system emphasizes local conditions and local candidates, that is when district magnitude is small or there is a large number of districts. This happens when average district magnitude is low. ${ }^{8}$ This leads to the following interactive hypotheses:

H6. Ideological Unity x Average District Magnitude: The negative effect

\footnotetext{
${ }^{8}$ District magnitude, the number of districts and the electoral system more generally also have an independent effect on the incentives of parties to coordinate across districts. In this article, however, we care about the effect of ideological unity conditional on the electoral system.
} 
of ideological unity on party nationalization is larger in countries with smaller average district magnitude.

H7. Ideological Unity $x$ Number of Districts: The negative effect of ideological unity on party nationalization is larger in countries with a larger number of districts.

In sum, if the goal is to spread nationally then parties are better off if they allow for some ideological diversity within, especially when the country's societal and institutional make-up exacerbate the saliency of local issues. Although some of the literature on ideological cohesion suggests that it is advisable to have an ideologically coherent platform for the success of a party, especially for the achievement of responsible party government (Bardi and Trechsel, 2014; Mair, 2013) this may run against the electoral interests of some parties. Following the conflict between responsible versus responsive duties of parties, we argue that ideological cohesion can have drawbacks if the goal is to expand nationally (especially under certain institutional and societal contexts).

\section{Data, Measurement and Empirical Strategy}

We test our hypotheses using an original dataset that includes both party level and country level variables across 142 parties in 20 European democracies (see Table 4 in the online appendix for a list of countries and parties). ${ }^{9}$ This allows us to specify and test a multilevel statistical model (MLM) that treats party as the level 1 and the country as the level 2. We estimate a random intercept model (Rabe-Hesketh and Skrondal, 2012; Gelman and Hill, 2006). Since variables constant within a country cannot account for within-country individual party variations the MLM model offers a test for both systemic and party level explanations.

\footnotetext{
${ }^{9}$ We exclude Netherlands and Slovakia because our measure of party nationalization is calculated as the distribution of electoral support across electoral districts in a country, but these two countries only have one electoral district (the country as a whole). However, we have conducted some robustness checks to see if their inclusion would affect the results and it does not. We calculate party nationalization scores for these two countries using their main administrative/territorial unit: 8 regions $k r a j$ in Slovakia and the 12 regions in the Netherlands. When including these two countries in the analyses (with this particular operationalization of the dependent variable) our results remain unchanged. The one exception is that the direct effect of leadership factionalism looses significance, which is not particularly concerning given that our main theory is about the conditional impact of this variable and the conditional impact does remain significant. We also exclude Greece and the Baltic countries because we do not have data on party organization for these countries.
} 
Level 1

Party Nationalization $\mathrm{i}, \mathrm{j}, \mathrm{t}=\beta_{0 \mathrm{i}, \mathrm{j}, \mathrm{t}-4}+\beta_{1}$ Ideological Unity $_{\mathrm{i}, \mathrm{j}, \mathrm{t}-4}$

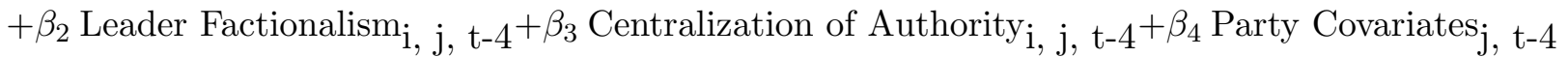

Level 2

$\beta_{0 \mathrm{i}, \mathrm{j}, \mathrm{t}-4}=\gamma_{0}$ Political Decentralization $_{\mathrm{i}, \mathrm{j}, \mathrm{t}-4}+\gamma_{1}$ Concentration of Diversity $_{\mathrm{i}, \mathrm{j}, \mathrm{t}-4}$ $+\gamma_{2}$ District Magnitude $_{\mathrm{i}, \mathrm{j}, \mathrm{t}-4}+\gamma_{3}$ Country Covariates $\mathrm{j}, \mathrm{t}-4^{+} \mu_{\mathrm{i}, \mathrm{j}, \mathrm{t}}$

Our theory posits that party organizational factors (in interaction with contextual factors) affect the likelihood that parties' electoral support will become nationalized. Although we do not exclude the possibility that party organization could change as a result of the extent of party nationalization, we believe that the direction of causality that we posit is more likely since party organization seems more difficult to change (Harmel, 2002) than a party's distribution of electoral support and also because we believe that party organization changes more as a result of poor electoral success, which as we show in the last section of this article, does not equate with poor party nationalization. ${ }^{10}$ Still, in order to minimize potential issues of endogeneity our independent variables are lagged several years with respect to our dependent variable. Our independent variables are measured in 2007 because this is the year for which we have data for the party organization variables, ${ }^{11}$ whereas our dependent variable - party nationalization- is measured at the first national legislative election after 2007 for each country. Descriptive statistics for all variables are presented in the online appendix.

\section{Dependent Variable: Party Nationalization}

Our dependent variable is party nationalization defined as the extent to which a party's electoral strength varies across the territory of a country. Highly nationalized parties are parties that obtain a relatively even support across electoral districts in a country, whereas territorialized parties are parties that obtain support only in one or a few electoral districts in the country. We operationalize party nationalization using Bochsler (2010)'s standardized party nationalization score which is based on the Gini coefficient of inequalities to capture the extent to which a party's electoral support is equally distributed across constituencies. The measure ranges from 0 (a party that receives 100 percent of its vote in one district) to 1 (a party that receives

\footnotetext{
${ }^{10}$ We further discuss aspects of possible reverse causality in the last section of the paper.

${ }^{11} \mathrm{~A}$ second wave of expert surveys is currently in the field.
} 
the same share of votes in all districts). ${ }^{12}$

For example, large centre-right and centre-left parties in Europe tend to have scores close to 1 indicating that these parties are highly nationalized: Spain's Socialist Party-PSOE (0.94), Norway's Norwegian Labour Party (0.92), Italy's Forza Italia (0.91) and UK's Conservative Party (0.9). However, nationalization is not only reserved to large political parties. There are several smaller parties that are also highly nationalized such as the Free Democratic Party in Germany (0.91), Federation of Greens in Italy (0.91), the Party of Italian Communists (0.91), the Greens in Sweden (0.89) or the Greens in Germany (0.82). At the low end of our measure (scoring close to 0) and capturing highly territorialized parties we find (not surprisingly) some regionalist parties: Italy's South Tyrolean People's Party (0.05), Spain's Basque National Party (0.08), and UK's Sin Feinn (0.2). Other regionalist parties, such as the Scottish National Party (0.37), have a slightly higher score since they are successful in quite a few constituencies, but are still considered quite territorialized. It is important to note however that not all highly territorialized parties are regionalist parties. For example, the Hungarian Justice and Life Party (MIEP) also has a very small nationalization score (0.12) and so do parties such as Switzerland's Labour Party (0.11) and Belgium's Socialist Party (0.32).

This brief overview of the extent to which parties are nationalized in Europe suggests two important points that we will emphasize throughout this article. First, party nationalization in Europe is not necessarily correlated with party size. ${ }^{13} \mathrm{Al}-$ though large parties tend indeed to be quite nationalized, this is not always the case, and we find a variety of political parties that are relatively small in terms of vote percentage and that are quite nationalized in terms of having an even distribution of votes across electoral districts. This suggests that party success and party nationalization should be treated as different dependent variables, and that explanations of party success are likely to differ from explanations of party nationalization. Second, territorialized parties are not always parties that are regionalist in terms of defending the cultural or ethnic interest of a particular region. There are numerous examples in Europe of non-regionalist parties that are territorialized since they have an uneven distribution of votes across electoral districts. This points to the fact that the explanation for territorialization of parties is not simply ideological.

Compared to various other measures of party and party system nationalization,

\footnotetext{
${ }^{12}$ See Bochsler (2010) for the precise formula to calculate the standardized party nationalization score. We calculated these scores using Bochsler (2010)'s macro file for Microsoft Excel program available at: http://www.bochsler.eu/pns/

${ }^{13}$ By party size we mean party electoral strength. In our dataset the correlation between party nationalization and party seat share is 0.58 , so although there is clearly a relationship, it is not perfect.
} 
the advantage of Bochsler's measure is that it weights the Gini coefficient for the size of territorial units (i.e. electoral districts) within a country, and for the number of districts in each country. This is particularly important when making cross-country comparisons, and also because some of our independent variables (such as average district magnitude) are correlated with the number of electoral constituencies in a country. Table 5 in the online appendix presents a list of sources for computing the nationalization measure and the election years for which data was collected.

\section{Party-Level Independent Variables}

Our key party-level independent variables are centralization of authority, leadership factionalism and ideological unity. These variables were generated by the Party Unity Study, an on-line expert survey conducted in 2007. Across countries, the variation in the number of respondents ranged from 5 to $35 .{ }^{14}$ Generally, the experts agreed across our organizational measures and the standard deviation of their responses was low (0.80). Their answers were aggregated by political party which resulted in a final score being attributed to each party on all organizational variables. The overall disagreement in the scores offered to each party is not dependent on the number of survey respondents. This is substantiated by a very low correlation (0.11 at sig. 0.01) between the aggregated party score and the standard deviations of expert responses for each party. Hence the reliability of our estimates is not related to the number of respondents to the expert survey.

Compared to other expert surveys on party politics already conducted in Europe and considering that no financial incentives were offered, the expert survey has received an average response rate comparable to other studies. Similar expert surveys received an average response rate of 23 per cent in Eastern Europe and 32 per cent in Western Europe (Benoit and Laver, 2007). The Party Unity expert survey received on average of almost 18 percent per cent from the Central East and West European experts combined. Further details of the survey and exact question wording are provided in the online appendix Table 7.

Our estimates of party organization variables have the advantage of providing de facto information on the intra-party politics. Other studies, which focus on analyzing party statutes have the disadvantage of reporting party organization from formal documents, which may not be followed closely by the party. ${ }^{15}$ The indicators as we describe them below, constitute three different aspects of party organization which

\footnotetext{
${ }^{14}$ The experts were party scholars specialized on each country, researchers and policy experts.

${ }^{15}$ For example, there is a high discrepancy between the official documents of FIDESZ in Hungary and the practice of authority within the party. The latter is better reflected by the expert scores on party centralization.
} 
do not always go together and are treated separately in our analysis. The association coefficients are very low: centralization and ideological unity 0.14; leadership factionalism and centralization -0.03; ideological unity and leadership factionalism -0.39 .

Centralization of power refers to the location and distribution of effective decisionmaking authority within the party with regards to the top national party organs. The concept captures the concentration of power at the central level and the topdown decision making process with regards to various party affairs. Experts were asked to assign a score from 1 to 5 to each party for the level of centralization in general decision-making, selection of candidates, and the distribution of party finances where 1 means very low centralization and 5 means very high centralization. With a high level of centralization was for example evaluated by the experts The National Front (FN) in France or the Flemish Interest in Belgium. At the lower end of centralization is the Green Party in France (score of 2.3) and also the Hungarian Socialist Party (MSZP).

Ideological unity refers to the programmatic cohesion of parties in terms of their overall ideology. A high score (maximum of 5) means that there is no conflict amongst party members with regards to the overall ideology of the party while a minimum score of 1 means complete disagreement over the party's programme. In our sample the level of ideological unity is not related to party family belonging across Europe. For example, a high score of 4.5 in ideological unity is for example attributed to the conservative oriented Popular Party (PP) in Spain, a similar score of high ideological unity is attributed to right-wing party The Flemish Interest (Vlaams Belang) in Belgium, and likewise a score of 4.3 was assigned to parties with leftist orientation such as the Communist Party of Bohemia and Moravia (KSCM).

Finally, leadership factionalism refers to the extent of divisions in the party central office or in other words the intra-party groups organized around different party leaders to act collectively as distinct blocs within the party. Experts rated each party for the extent of factionalism based on the personal attraction of individual leaders from 1 (none) to values of 5 (a great deal). At the low end of this variable spectrum is a party such as The New Flemish Alliance (N-VA) in Belgium with a score of 1.5 whilst at the higher end of the spectrum we find parties such as The Green Party in France (score of 4). A moderate score of 3 on leadership factionalism was assigned to the United Left Party in Spain. Leadership factionalism is a more transient measure and reflects the extent to which party leadership is is divided and the current party leader is being contested. 16

\footnotetext{
${ }^{16}$ This can happen in the context of both high and low party ideological unity. For example high
} 
In addition to these party organization variables, we control for two additional party-level factors: regionalist party and party age. Our variable regionalist party captures whether a party is regional or ethnic in nature based on the Chapel Hill Expert Survey classification of party families (Bakker et al., 2012). ${ }^{17}$ We include this control because political parties defending ethno-territorial groups are ideologically motivated to compete only in a portion of the territory of a country (instead of the entire country). We thus expect regional parties to be less likely to become fully national. We also control for party age since we think that older political parties have had the time to develop the necessary resources, experience and voter attachments to successfully build nation-wide party platforms and are thus more likely to be nationalized.

\section{Country-Level Independent Variables}

Concentration of diversity. Scholars have traditionally measured the amount of social diversity through fractionalization measures (Alesina et al., 2003), which capture the number of ethnic, religious and linguistic groups in a country. These fractionalization measures however do not capture the extent to which social diversity overlaps with geographic units in a country. To measure the geographic concentration of a variety of key social cleavages (language, religion, income) we rely on Selway (2011)'s CIMMSS dataset. ${ }^{18}$ For each social cleavage (language, religion, income) Selway calculates the extent to which groups within that cleavage (i.e. language groups within the linguistic cleavage) are identically distributed across regions or districts in a country or whether each language group is concentrated in one region or district.

For example, one such measure - "language-geography cross-cuttingness" - reflects the degree to which language and territory overlap: low values indicate that individuals of language A mostly live in region 1 whereas individuals of language B mostly live in region 2 (i.e. language and geography reinforce each other); in contrast, high values mean that individuals of language A are equally divided in terms of the region where they live, and so are individuals of language B (i.e. language

leadership factionalism was present in 2007 in parties with low ideological unity such as the Civic Platform in Poland (PO), medium unity such as the Democratic and Social Centre in Portugal (CSD/PP) or high levels of unity like the Worker's Party in Hungary (MUNK).

${ }^{17}$ The only change that we make to the Chapel Hill Dataset is that we include Germany since we consider the CSU to be a separate party from CDU and a regional political party). Our coding of the dependent variable treats the CSU as an independent party from the CDU (which it is organizationally) and thus it appears to be very regionalized. In addition, the CSU has no intent in nationalizing since its alliance with the CDU gives it national presence.

${ }^{18}$ https://sites.google.com/site/joelsawatselway/CROSS-CUTTING-CLEAVAGES-DATA 
and geography cross-cut). We invert Selway's measures of cross-cuttingness (for each of the three social cleavages) so that higher values indicate more geographic concentration (i.e. more overlap between geography and groups within a cleavage) and lower values indicate more geographic dispersion (i.e. more cross-cuttingness between geography). We end up with three different measures: concentration of language, concentration of religion and concentration of income, which we combine into an index called Concentration of Diversity (which is the average of the three measures). ${ }^{19}$ We log the index because its distribution is highly skewed.

Electoral system. We use two measures to capture the extent to which the electoral system increases the saliency of local (as opposed to national) interests: Average District Magnitude and Number of Districts. Our measure Average District Magnitude comes from Beck et al. (2001) and it is the average district magnitude of the House. ${ }^{20}$ Our measure of Number of Districts is based on our own calculations. Both variables are logged because their distribution is highly skewed. As these two variables are highly correlated, we exclude the number of districts from models reported in Table 1. Another key electoral system measure that is closely related with district magnitude is a country's threshold of representation, yet we opted not to use this variable for two reasons: first, threshold of representation is a more elusive concept than district magnitude or number of districts because it is often operationalized as a combination of many different variables (district magnitude, number of districts, legal thresholds, size of the legislature...). Second, the thresholds of representation in a country does not really capture the "localization of politics" or the "saliency of local interests" which is the crux of our argument presented.

Political decentralization. We use Hooghe et al. (2015)'s "representation" variable from the Regional Authority Index dataset, which captures the extent to which a country's subnational tier is endowed with an independently elected legislature and executive. Hooghe et al. (2015) code each regional tier in a country as follows: $0=$ no regional assembly; $1=$ an indirectly elected regional assembly; $2=$ a directly elected assembly; $0=$ the regional executive is appointed by central government; $1=$ dual executives appointed by central government and the regional assembly; $2=$ the regional executive is appointed by a regional assembly or directly elected. They

\footnotetext{
${ }^{19}$ We create an index of concentration of diversity because the three indicators from its composition capture together diversity in different forms while they are not intercorrelated. In other words the index tells us whether a country is experiencing some form of concentrated diversity across one, two or all three dimensions and with which intensity.

${ }^{20}$ In mixed systems, the DPI dataset calculates the weighted average MDMH by first calculating the average MDMH of each tier (number of seats/number of districts, for each tier), and then averaging these averages, where each tier is weighted by the number of seats.
} 
then add up the scores for the assembly and for the executive for each regional tier. In our sample the measures ranges from 0 (lowest levels of political decentralization) to 5.7 (highest levels of political decentralization).

New democracy. We include a dummy variable indicating whether the country is an old or new democracy. This variable takes the value of 0 for countries that have recently transitioned to democracy, which includes third wave democracies in Southern European and post-communist countries (Czech Republic, Hungary, Poland, Portugal, Romania, Slovakia, Spain). We run some robustness tests with an alternative variable -years of democracy - that measures the years since the last democratic transition for each of our countries. We build this measure using the POLITY dataset and we consider a transition to democracy when a country starts having a polity score (new POLITY2 variable) of 6 or more. The results of our analyses with this different operationalization hold.

\section{Results}

The empirical analysis proceeds in two stages. We first test the direct effect of our party organization and contextual control variables, and then we test several models including cross-level interactions between country-level factors and partylevel organizational features. Table 1 presents separate models that include only party-level variables (model 1); only country-level variables (model 2) and both party-level and country-level variables (model 3). The results from models 1 and 3 suggest that our three party organization variables have the expected effect on party nationalization, although "party centralization" fails to reach statistical significance.

We predicted that ideological unity within parties is detrimental for spreading nationally (H4) because it prevents parties from adapting to a variety of local conditions. Table 1 indeed shows that ideological unity has the expected negative and statistically significant effect on party nationalization. The significant effect of this variable remains when we include our contextual variables in the analysis (Model 3). ${ }^{21}$ In many cases, a degree of programmatic unity is traded for uniform electoral success across the country in order to appeal to more voters. For example, The Greens in Germany, Venstre the liberal party in Denmark and the Civic Platform in Poland are all illustrative cases of the negative relationship between ideological

\footnotetext{
${ }^{21}$ The effect of ideological unity maintains when controlling for party size measured as share of votes and share of seats. Our argument and results hence show that in the electoral arena less ideological unity contributes to party nationalization. Conversely, in the parliamentary arena, more ideological unity might be required for a party to act as a unitary bloc in roll-call votes. As we explained in the theory section this demonstrates that parties are faced with conflicting strategies in different arenas, which is something worth exploring in future research.
} 
Table 1: Direct Effect of Party-Level and Country-Level Variables

\begin{tabular}{|c|c|c|c|}
\hline Dependent Variable: Party Nationalization & M1 & M2 & M3 \\
\hline \multirow[t]{2}{*}{ Ideological Unity } & $-.114^{* * *}$ & & $-.109^{* * *}$ \\
\hline & $(.04)$ & & $(.04)$ \\
\hline \multirow{2}{*}{ Leadership Factionalism } & $-.076^{* *}$ & & $-.064^{* *}$ \\
\hline & $(.03)$ & & $(.03)$ \\
\hline \multirow[t]{2}{*}{ Party Centralization } & .050 & & .039 \\
\hline & $(.03)$ & & $(.03)$ \\
\hline \multirow[t]{2}{*}{ Regionalist Party } & $-.410^{* * *}$ & & $-.390 * * *$ \\
\hline & $(.07)$ & & $(.07)$ \\
\hline \multirow[t]{2}{*}{ Party Age } & .000 & & .000 \\
\hline & $(.00)$ & & $(.00)$ \\
\hline \multirow[t]{2}{*}{ Concentration of Diversity $(\log )$} & & $-.232^{* *}$ & -.126 \\
\hline & & $(.10)$ & $(.08)$ \\
\hline \multirow{2}{*}{ Political Decentralization } & & -.024 & $-.028 *$ \\
\hline & & $(.02)$ & $(.02)$ \\
\hline \multirow[t]{2}{*}{ Average District Magnitude (log) DPI } & & .033 & .025 \\
\hline & & $(.03)$ & $(.03)$ \\
\hline \multirow[t]{2}{*}{ New Democracy (dic) } & & .005 & -.042 \\
\hline & & $(.07)$ & $(.06)$ \\
\hline \multirow{2}{*}{ Constant } & $1.150^{* * *}$ & .271 & $.966^{* * *}$ \\
\hline & $(.20)$ & $(.21)$ & $(.28)$ \\
\hline No. of cases & 142 & 145 & 142 \\
\hline No. of countries & 20 & 20 & 20 \\
\hline $\operatorname{sigma~}_{u}$ & .07 & 0.09 & 0.07 \\
\hline sigma $_{e}$ & .20 & 0.24 & 0.20 \\
\hline Rho & .09 & 0.14 & 0.09 \\
\hline Chi2 & 57.03 & 11.51 & 69.15 \\
\hline R2 & 0.32 & 0.15 & 0.39 \\
\hline
\end{tabular}

Sig: ${ }^{*} p<0.10,{ }^{* *} p<0.05,{ }^{* * *} p<0.01$ 
unity and nationalization. They all have high levels of nationalization but exhibit ideological heterogeneity. These findings are in line with the catch-all literature following Kirchheimer (1966) whereby parties need to lose a bit of their ideological package in order to appeal to a larger pool of voters. In contrast, parties that are ideologically very cohesive tend to be less nationalized such as for example, The Justice and Life Party in Hungary or the New Flemish Alliance and the Socialist Party in Belgium. Our results reinforce the importance of party programmatic strategy for nationalization, especially with regards to flexibility in their ideological platform.

We also stipulated that both centralization of authority and the absence of leadership factionalism (i.e. control and leadership consensus) within parties should increase the likelihood of a party being nationalized (H1 and $\mathrm{H} 2$ ). The results from Table 1 suggest that "leadership factionalism" is indeed negatively associated with nationalization (and statistically significant), which confirms the expectations of hypothesis 2. Across our European sample we find high leadership factionalism in parties with low ideological unity (such as the Civic Platform in Poland or the Socialist Party in Portugal) and also in parties with high ideological unity (for example the Worker's Party in Hungary or Reform Movement in Belgium). Considering the positive impact of ideological heterogeneity and in line with our expectations, we find that parties in the first group (high leadership factionalism, low ideological unity) exhibit slightly higher levels of nationalization. This also points towards a stronger impact of ideological unity on nationalization compared to leadership factionalism as also shown by the coefficients in table 1 .

"Party centralization" although positively associated with party nationalization (as expected), is not statistically significant. In other words, party centralization does not seem to influence the extent to which a party becomes nationalized. This non-finding could be explained by the fact that our measure of "party centralization" is a measure capturing three different aspects of centralization of authority with potentially countervailing effects on nationalization. For example, whereas centralization of decision-making and centralization of resources might be positively related to nationalization, centralization of candidate selection might actually be negatively associated with nationalization since it might make the party less adaptable to diverse local constituencies and less appealing to new party elites. ${ }^{22}$ Our data does not allow us to test whether these different dimensions of centralization

\footnotetext{
${ }^{22}$ In a study of the success of ethnic parties in India, Chandra (2004) argues that parties with a centralized structure tend to fail because they are unable to incorporate new political elites. In contrast, parties that have a more competitive procedure for selecting candidates (more decentralized parties) are better able to broaden their elite profile and obtain more electoral success.
} 
might have different (and perhaps opposing) effects; but this is certainly an avenue for further research.

\section{Organizational and ideological strategies in context}

The second step of our analysis examines how party organization variables are conditioned by specific country-level institutional and societal factors. We capture this conditionality through three cross-level interaction models presented in Table 2. Our first conditional expectation (H3) is that the negative effect of leadership factionalism on nationalization should be particularly strong when countries are politically decentralized. We capture this conditionality in model 1 which includes an interaction between "leadership factionalism" and "political decentralization." As we cannot interpret the effect and the significance of the interaction term from the coefficients in the table (Brambor, Clark and Golder, 2006), we plot the relevant marginal effects in Figure 2.

Figure 2 shows that leadership factionalism has a negative and significant effect on party nationalization in highly decentralized and federal countries. The negative effect increases as decentralization increases (for example, nationalization is expected to decrease by 20 percentage points, when, in conditions of leadership factionalism, we compare parties from a highly centralized country such as Luxembourg with parties from a highly decentralized country such as Belgium). ${ }^{23}$ It also shows that there is no statistically significant effect of leadership factionalism on nationalization when the country is highly centralized. This is not due to the fact that centralized countries are less likely to have parties with leadership factionalism; in fact there is variation in leadership factionalism across all levels of political decentralization. ${ }^{24}$ What it means is that in centralized countries, internal party factions are likely to be less powerful and more nationally-oriented and thus likely to want to pursue a national strategy. In contrast, in federal or decentralized countries factions within parties are likely to have more power (due to the decentralized nature of the state) and are likely to be concerned with their particular local or regional issues. In decentralized or federal contexts then leadership factionalism will make it difficult for a party to coordinate a national strategy across all territorial constituencies in the country.

Our second set of conditional expectations are centred around the effect of ideological unity on party nationalization. We argued that ideologically united parties

\footnotetext{
${ }^{23}$ The percentage of observations which fall within the significance area is 57.7

${ }^{24}$ The correlation coefficient between political decentralization and leadership factionalism is quite low $(0.17)$.
} 
Table 2: Models with Interactions

\begin{tabular}{|c|c|c|c|c|}
\hline Dependent Variable: Party Nationalization & M1 & $\mathrm{M} 2$ & M3 & M4 \\
\hline Ideological Unity & $\begin{array}{c}-.105^{* * *} \\
(.04)\end{array}$ & $\begin{array}{c}-.248^{* * *} \\
(.08)\end{array}$ & $\begin{array}{c}-.016 \\
(.09)\end{array}$ & $\begin{array}{c}-.428^{* *} \\
(.20)\end{array}$ \\
\hline Leadership Factionalism & $\begin{array}{l}.073 \\
(.06)\end{array}$ & $\begin{array}{c}-.072^{* *} \\
(.03)\end{array}$ & $\begin{array}{c}-.072^{* *} \\
(.03)\end{array}$ & $\begin{array}{c}-.063^{* *} \\
(.03)\end{array}$ \\
\hline Party Centralization & $\begin{array}{l}.045 \\
(.03)\end{array}$ & $\begin{array}{l}.045 \\
(.03)\end{array}$ & $\begin{array}{l}.048 \\
(.03)\end{array}$ & $\begin{array}{l}.041 \\
(.03)\end{array}$ \\
\hline Political Decentralization & $\begin{array}{l}.076^{*} \\
(.04)\end{array}$ & $\begin{array}{c}-.029^{*} \\
(.01)\end{array}$ & $\begin{array}{c}-.024^{*} \\
(.01)\end{array}$ & $\begin{array}{c}-.025 \\
(.02)\end{array}$ \\
\hline Concentration of Diversity (log) & $\begin{array}{c}-.124^{*} \\
(.07)\end{array}$ & $\begin{array}{c}-.108 \\
(.08)\end{array}$ & $\begin{array}{c}-.124 \\
(.08)\end{array}$ & $\begin{array}{l}.558 \\
(.42)\end{array}$ \\
\hline Average District Magnitude (log) (DPI) & $\begin{array}{l}.031 \\
(.02)\end{array}$ & $\begin{array}{c}-.209^{*} \\
(.12)\end{array}$ & & $\begin{array}{l}.026 \\
(.03)\end{array}$ \\
\hline Number of Electoral Districts (log) & & & $\begin{array}{c}.085 \\
(.10)\end{array}$ & \\
\hline Leadership Factionalism $\times$ Political Decentralization & $\begin{array}{c}-.045^{* * *} \\
(.02)\end{array}$ & & & \\
\hline Ideological Unity $\times$ Average District Magnitude (log) & & $\begin{array}{l}.065^{*} \\
(.03)\end{array}$ & & \\
\hline Ideological Unity $\times$ Number of Electoral Districts $(\log )$ & & & $\begin{array}{c}-.029 \\
(.03)\end{array}$ & \\
\hline Ideological Unity $\times$ Concentration of Diversity (log) & & & & $\begin{array}{c}-.172^{*} \\
(.10)\end{array}$ \\
\hline Regionalist Party & $\begin{array}{c}-.376^{* * *} \\
(.06)\end{array}$ & $\begin{array}{c}-.371^{* * *} \\
(.07)\end{array}$ & $\begin{array}{c}-.370^{* * *} \\
(.07)\end{array}$ & $\begin{array}{c}-.388^{* * *} \\
(.07)\end{array}$ \\
\hline Party Age & $\begin{array}{r}.000 \\
(.00)\end{array}$ & $\begin{array}{r}.000 \\
(.00)\end{array}$ & $\begin{array}{l}.000 \\
(.00)\end{array}$ & $\begin{array}{l}.000 \\
(.00)\end{array}$ \\
\hline New Democracy (dic) & $\begin{array}{c}-.039 \\
(.05)\end{array}$ & $\begin{array}{c}-.033 \\
(.06)\end{array}$ & $\begin{array}{c}-.039 \\
(.05)\end{array}$ & $\begin{array}{r}-.017 \\
(.06)\end{array}$ \\
\hline Constant & $\begin{array}{c}.603^{* *} \\
(.28)\end{array}$ & $\begin{array}{c}1.487^{* * *} \\
(.39)\end{array}$ & $\begin{array}{l}.718^{*} \\
(.41)\end{array}$ & $\begin{array}{c}2.199 * * * \\
(.79)\end{array}$ \\
\hline No. of cases & 142 & 142 & 142 & 142 \\
\hline No. of countries & 20 & 20 & 20 & 20 \\
\hline $\operatorname{sigma}_{u}$ & 0.04 & 0.06 & 0.05 & 0.07 \\
\hline $\operatorname{sigma}_{e}$ & 0.20 & 0.20 & 0.20 & 0.20 \\
\hline Rho & 0.04 & 0.09 & 0.07 & 0.11 \\
\hline Chi2 & 87.30 & 75.08 & 74.99 & 71.06 \\
\hline $\mathrm{R} 2$ & 0.43 & 0.41 & 0.40 & 0.41 \\
\hline
\end{tabular}

Sig: ${ }^{*} p<0.10,{ }^{* *} p<0.05,{ }^{* * *} p<0.01$ 
Figure 2: Marginal Effects of Leadership Factionalism

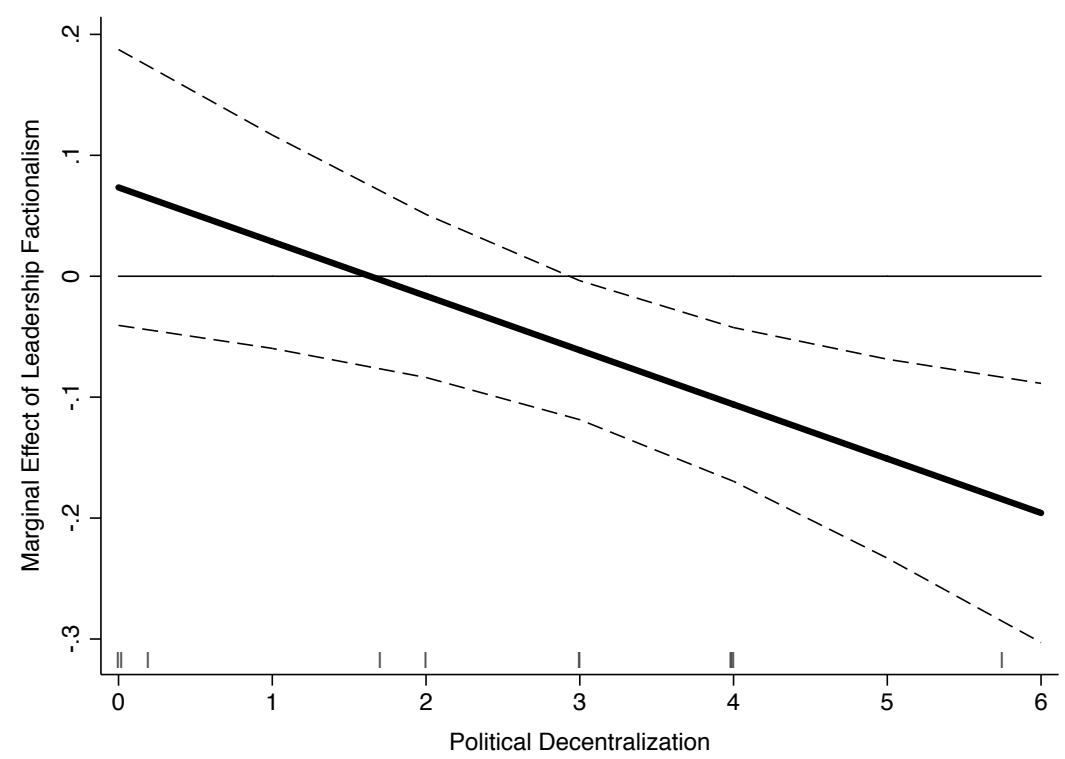

should have a harder time appealing to a diversity of interests across electoral constituencies in the country and thus should be less likely to become nationalized. This negative effect of ideological unity on party nationalization should be particularly strong for parties in countries where local interests are salient. We identified three factors that contribute to the saliency of local interests in a country: geographically concentrated diversity, a low district magnitude electoral system and a large number of electoral districts. We thus expect a significant interaction between ideological unity and these contextual factors. ${ }^{25}$ This conditionality is captured by the interaction terms in models 2, 3 and 4 in Table 2, and the relevant marginal effects are plotted in Figure 3.

The top graph in Figure 3 presents the marginal effect of ideological unity (yaxis) as district magnitude changes (x-axis). The graph shows that ideologically united parties have a negative (and significant) effect on party nationalization especially among low-district magnitude electoral systems. This negative effect gets smaller (but still significant) as district magnitude increases, which suggests that as interests become less localized it is easier for parties to nationalize and their ideological strategies matter less for nationalization. At very high levels of district magnitude $(\mathrm{DM}(\log )>2.7$, i.e. $\mathrm{DM}>15)$ the effect of ideological unity becomes non-

\footnotetext{
${ }^{25}$ We also tried the interaction with a fourth contextual factor - political decentralization - as we believe that to some extent it also captures the degree to which politics is localized. The results of this fourth interaction are presented in the online appendix (Figure 6) and go in the expected direction of our theory.
} 
Figure 3: Marginal Effects of Ideological Unity
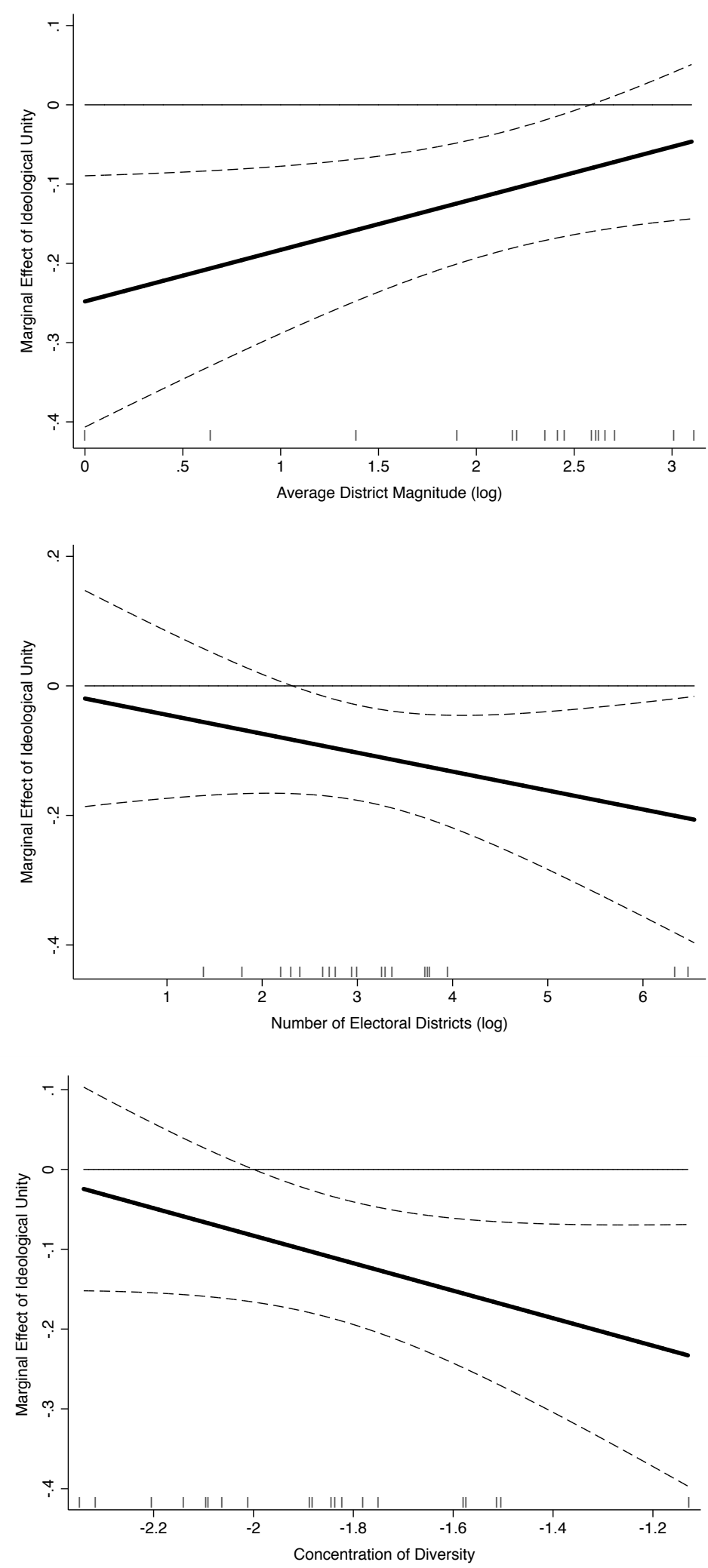
significant (since the confidence interval bands cross 0 ). The rug plot that overlays the marginal effects graph suggests that a substantial number of observations lie in the significant portion of the graph (about 78.07 percent of our sample), which according to Berry, Golder and Milton (2012) is indicative of support for our hypothesis. The middle graph also supports our expectations. It shows that ideologically united parties have a negative (and significant) effect on party nationalization especially as the number of electoral districts increases above 11 (i.e. as politics becomes more localized). In contrast ideological unity has no statistically significant effect when there are few electoral districts that is when the electoral system promotes national interests.

The bottom graph shows the marginal effect of ideological unity (y-axis) as the concentration of diversity in a country changes (x-axis). Ideologically united parties have a negative (and significant) effect on party nationalization, and this effect becomes even stronger as a country's diversity becomes more and more territorially concentrated. This confirms what we expected because as a country becomes more territorially diverse it becomes harder for parties to construct credible and effective cross-district alliances. We also see that when a country is not territorially diverse (that is when interests are not as locally diverse) the extent of ideological unity of a party does not seem to matter. ${ }^{26}$ The rug plot suggests again that a substantial percentage of observations lies in the region of significance (65 percent based on our calculations). These results strongly confirm our expectations of the effect of ideological unity on party nationalization and the mechanisms associated with this effect. $^{27}$ In order to provide some further robustness, we ran this same interaction with alternative measures of geographic concentration of social diversity from Lublin (2015)'s dataset and from Alesina and Zhuravskaya (2011)'s dataset on geographical segregation. ${ }^{28}$

\footnotetext{
${ }^{26}$ Note that the correlation coefficient between ideological unity and concentration of diversity is 0.08 , which means that there is variation in ideological unity in countries that are diverse and also in countries that are not diverse.

${ }^{27}$ In fact, we would expect ideological unity to have a negative effect on party nationalization in countries with both territorially concentrated diversity and an electoral system promoting local interests. We tested this triple interaction (between the electoral system variables, highly concentrated diversity, and ideological unity) and our expectations hold. Results for these analyses are available from the authors upon request.

${ }^{28}$ Lublin (2015)'s dataset has a measure of the effective number of electorally relevant ethno-regional groups (EREG) and Alesina and Zhuravskaya (2011)'s dataset provides a measure of segregation for three different cleavages (language, religion and ethnicity). When running our analyses with these alternative measures our results hold. See Figure 7 in the online appendix.
} 


\section{Alternative theories and robustness tests}

Our theory explains that to become nationalized parties need to a) build a party organization that can field candidates everywhere and b) win everywhere. Our empirical focus in this article has been on the later - the nationalization of electoral support, which we operationalize as the degree to which a party's electoral support is evenly distributed across electoral districts. However, building a nation-wide party organization that fields candidates everywhere is a pre-requisite to obtaining nation-wide electoral support, and one might wonder the extent to which these dimensions are related and whether the same factors explain both aspects of party nationalization.

We think that these two dimensions of nationalization are strongly related because the decision of parties to develop a nation-wide organization and field candidates across the entire territory of a country is often determined by the expectation that these parties have about whether they can win across the territory. If parties think that they are unlikely to win votes across the territory, they will decide against fielding candidates everywhere since that would mean wasting precious resources without any electoral yield. This is similar to the strategic decision of political entrepreneurs in plurality systems, which explains intra-district coordination: parties will decide not to compete in districts where they think they will not be competitive, which helps reduce the effective number of electoral parties to two (at the district level) (Duverger, 1954; Clark and Golder, 2006). So in most cases we should see a strong relationship between the extent to which parties field candidates across the territory and the extent to which parties obtain even electoral support across the territory. Empirically speaking these two dimensions are indeed highly correlated in our dataset (0.92), which means that in the vast majority of cases parties that field candidates everywhere also tend to win everywhere. ${ }^{29}$

Yet it would still be interesting to test whether our party organization variables

${ }^{29}$ There are a handful of parties in Europe that are exceptions to this strong relationship between organizational and electoral aspects of nationalization: Alliance for the Future of Austria (BZO), the Finnish Christian Democrats (KD), the Hungarian democratic union (UDMR) in Romania, the Greens in Germany and Labour in the UK. These parties field candidates across the entire territory of a country but fail to win consistent support across the territory. The question of why parties might behave this way is an interesting one, although not the focus of our article. For example, some traditionally nationalized parties might have difficulty anticipating changes in electorate preferences in their country and find themselves loosing support in certain regions of the country, while still fielding candidates everywhere. This might account for the cases of the Labour Party in the UK or the Finish Christian Democratic Party in Finland. Another potential explanation could be that some parties with mostly regional support end up developing national aspirations and national organizational strategies by virtue of consistently participating in government coalitions at the national level. This would be the case of the Greens in Germany or the Hungarian democratic union (UDMR) in Romania, which field candidates everywhere but only receive support regionally. 
have a similar (or different) impact on the extent to which parties field candidates across electoral districts. In order to do this we run our main analyses with a different dependent variable measuring the percentage of territorial units where a political party runs in elections. This measure (which we call territorial coverage) is based on Caramani $(2004,61)$ and Bochsler (2010). The results of these analyses are presented graphically in Figure 4 (the full regressions are presented in Table 8 in the online appendix) and suggest that our party organization variables similarly explain fielding candidates everywhere and winning everywhere. This confirms our expectation that the decision to field candidates everywhere is probably highly influenced by the expectation that parties have formed about where they will win.

Figure 4: Marginal effects of cross-level interactions with territorial coverage as dependent variable
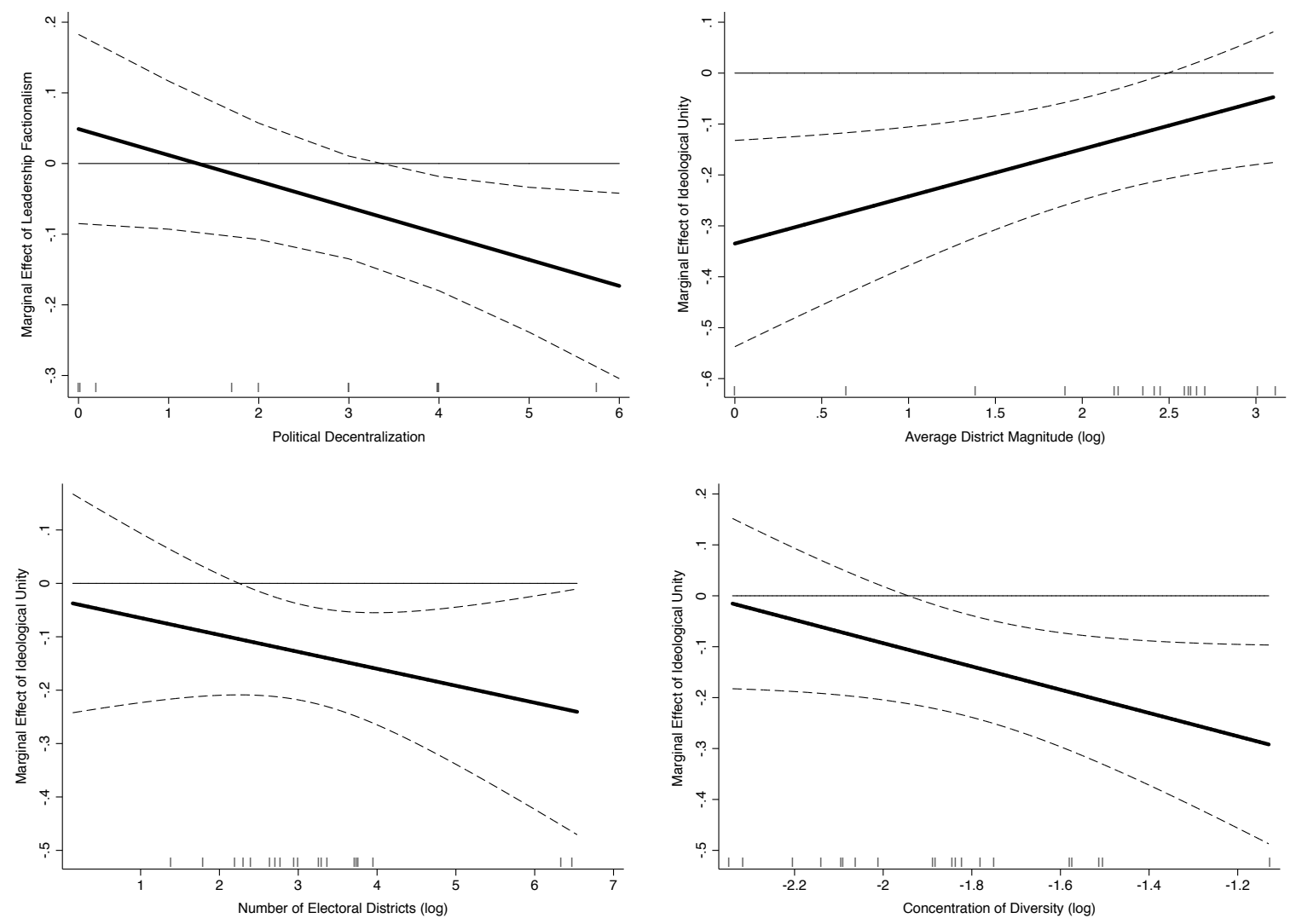

A second aspect of our theory that requires more careful examination is the assumption that parties aspire to be major political players at the national level, and that to do so they must garner extensive support across the territory of a country. Yet parties defending ethno-territorial groups often have no aspiration to fully nationalize. They are interested in gaining electoral support in a few districts, 
but not the entire country. In our analyses we account for this by controlling for whether a party is regionalist or not. As expected, the regression results from tables 1 and 2 show that being a regionalist party has a large and statistically significant negative effect on party nationalization. Yet despite the inclusion of this control variable, our key theoretical story about the importance of party organization holds. However, for further robustness we can run our analyses excluding all parties that are regionalist. This reduces our sample (which is not ideal) but allows to show that the exclusion of ethno-regional parties does not bias our results. Tables 9 and 10 and Figure 8 in the online appendix show that our main findings hold when excluding all ethno-regional parties.

A third potential issue has to do with the distinction between our dependent variable "party nationalization" and "party electoral success." While recent scholarship on party organization has been mostly interested in explaining party electoral success (Janda and Colman, 1998; Tavits, 2011; Greene and Haber, 2015; Ishiyama, 2001; Mylonas and Roussias, n.d.) our focus is on explaining party nationalization. We argue that party nationalization and party electoral success are indeed related ${ }^{30}$ but they are not the same thing, and they should be theorized separately. Figure 5 shows a scatterplot of these two variables: a party with low levels of electoral success might score very high on our measure of party nationalization because it has obtained similar electoral results nation-wide. For example, in Sweden, the Worker's Party of Social Democrats (SAP) and the Environmental Party the Greens (MP) have a similar high party nationalization score ( 0.88 and 0.87 respectively) but their electoral gains in the 2010 elections were completely different (30.5 and 7.3 percentage points respectively). For this reason, we do not expect our argument to apply to party electoral success.

Table 3 tests our base model with a party's electoral success as the dependent variable (instead of party nationalization), and it shows that neither "ideological unity" nor "leadership factionalism" are statistically significant predictors of party electoral success. However, we do find that "party centralization" is positively and significantly related to electoral success: more centralized parties are more likely to be electorally successful. This finding is in line with existing research that suggests that organizational strength (Tavits, 2011) and domination by office holders (Ishiyama, 2001) are positively related with good electoral performance. The divergence of effects between electoral success and nationalization further confirms that what drives party electoral success is not what drives party nationalization, and that these outcomes should be studied separately.

\footnotetext{
${ }^{30}$ The correlation between the two variables in our dataset is 0.59 .
} 
Table 3: Main model with electoral success as the dependent variable

\begin{tabular}{lcc} 
Dependent Variable: Electoral Success & $\mathrm{M} 1$ & $\mathrm{M} 2$ \\
\hline Ideological Unity & -2.292 & -2.274 \\
& $(1.87)$ & $(1.97)$ \\
Leadership Factionalism & 1.750 & 2.533 \\
& $(1.60)$ & $(1.70)$ \\
Party Centralization & $3.898^{* *}$ & $3.654^{* *}$ \\
& $(1.67)$ & $(1.76)$ \\
Party Age & $.067^{* *}$ & $.082^{* * *}$ \\
& $(.03)$ & $(.03)$ \\
Regionalist Party & $-12.021^{* * *}$ & \\
& $(3.52)$ & \\
Concentration of Diversity $(\log )$ & .299 & .315 \\
& $(3.55)$ & $(3.68)$ \\
Political Decentralization & -.816 & -.961 \\
& $(.66)$ & $(.70)$ \\
Average District Magnitude $(\log )$ & .298 & .376 \\
& $(1.08)$ & $(1.17)$ \\
New Democracy $($ dic $)$ & -3.146 & -4.292 \\
& $(2.54)$ & $(2.80)$ \\
Constant & 6.917 & 6.384 \\
& $(13.25)$ & $(14.15)$ \\
\hline No. of cases & 137 & 124 \\
No. of countries & 20 & 20 \\
\hline Sig: ${ }^{*} p<0.10,{ }^{* *} p<0.05,{ }^{* * *} p<0.01$ & & \\
& &
\end{tabular}


Figure 5: Scatterplot: Electoral Success and Party Nationalization

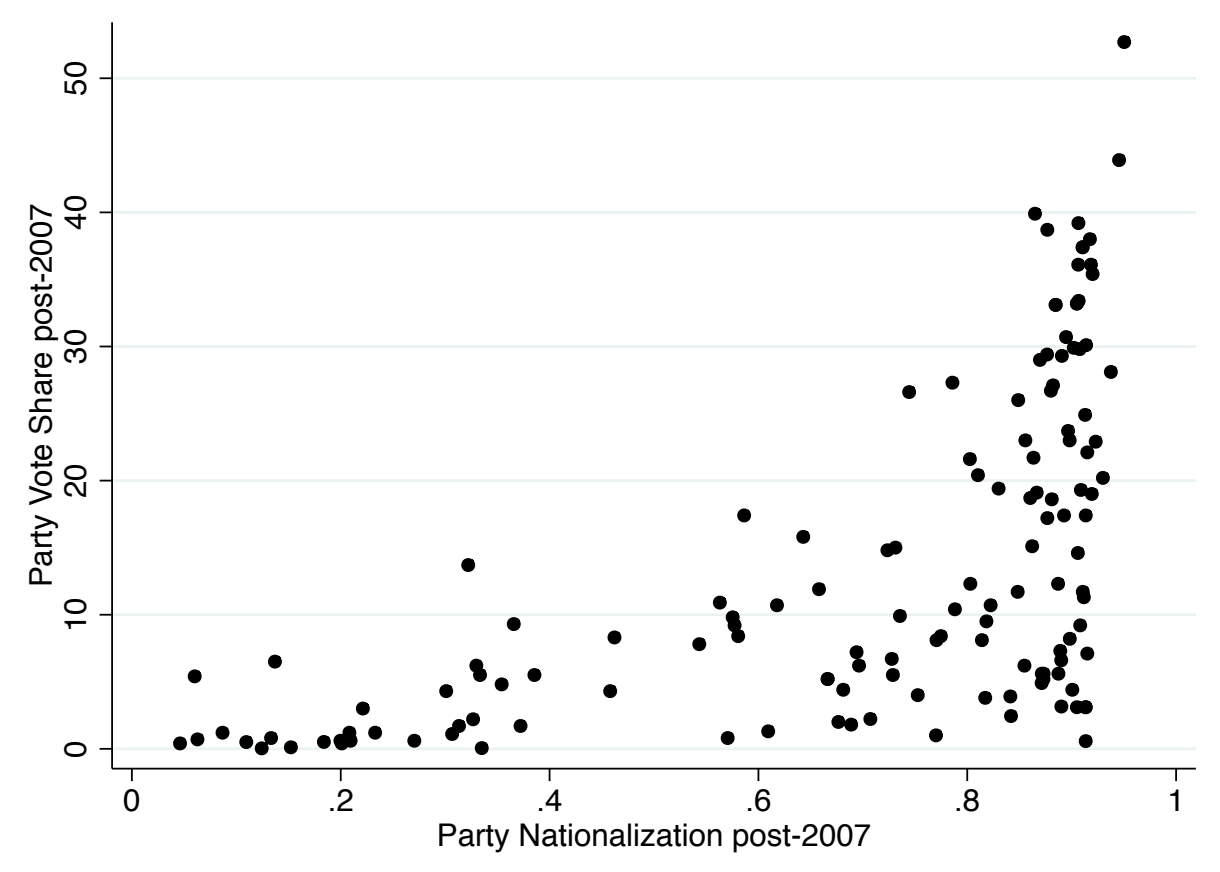

Finally, a fourth potential issue has to do with the direction of causality since there might be a reverse relationship between nationalization and party organization. We do not exclude this possibility and we believe that this relationship requires further exploration in a longitudinal study. To provide a first exploration of this issue we have collected additional data on party nationalization for the election year prior to 2007 (the year for which we have party organization data) and we have run a few models with our party organizational measures as dependent variables. In most models party nationalization is not significant, which lends less support to the hypothesis of a different causal story. The only exception is the model in which leadership factionalism is the dependent variable: party nationalization appears to discourage leadership factionalism. This is not surprising since successful nationalization means a successful coordination across districts which should increase the prestige and power of party leadership inside the party rather than diminish it. ${ }^{31}$ The issue of reverse causation however requires further elaboration and investigation in a longitudinal study. What we can claim in our paper is that there is a clear a strong relationship between the organizational features of political parties and their nationalization of electoral support. Further research should disentangle

\footnotetext{
${ }^{31}$ Results of these models with a lagged party nationalization variable are available from the authors upon request.
} 
exactly how this relationship unfolds over time.

\section{Conclusions}

This article provides the first empirical study of how parties' organizational structure affects whether or not parties become nationalized. To this date the existing literature has mostly focused on country-level variation in nationalization and on institutional or sociological influences to the formation of nation-wide parties and party systems. In contrast, we offer a party level approach to nationalization and we posit that one has to investigate its variation across parties within the same country and across countries.

We argue that party organization plays an important role in responding to the challenges or costs of nationalization: the organizational challenge and the electoral challenge. In particular we focus on three aspects of organization that are commonly identified in organization theory and in the literature on political parties (centralization of authority, leadership factionalism and ideological unity) and we specify how they relate to these two challenges and to the ability of parties to spread nationally.

We find that having leadership consensus (i.e. low leadership factionalism) is key to overcoming the organizational challenge of recruiting and fielding candidates everywhere and building a broad national party organization. This 'strategic fit' works especially when countries are already very decentralized politically. Second, we find that ideological heterogeneity is key to overcoming the electoral challenge of having to appeal to a potentially diverse set of interests. Consistent with this argument we show that ideological heterogeneity helps parties nationalize. This is another 'strategic fit' for an environment which includes geographically diverse countries and/or countries with electoral systems that localize interests. In sum, if the goal is to spread nationally then parties are better off if they allow for some ideological diversity within (flexibility) while assuring that their leadership remains fairly uncontested (i.e. leadership consensus). Finally, we do not find an effect of party centralization on party nationalization, yet party centralization seems to be a strong predictor of electoral success. This further supports our claim that electoral success and nationalization, while related, are different concepts and require different explanations.

This article contributes to the literature on party development on several fronts. First, by bringing the analysis to the party-level and focusing on party organization we are able to explain some crucial party-level variation in nationalization that had 
been previously ignored in the literature. Second, our article opens the door to more fine-grained analysis of the effects of party organization on political outcomes which is in line with a relatively new research agenda and ongoing data-collection projects on party organization. Third, this article opens the door to a less deterministic view of party nationalization; one in which parties have some margin to affect the outcome (constrained of course by their institutional and societal environment), and where parties can change over-time if they decide to modify their internal structures. As Caramani (2004) suggests "[...] the erosion of territorial cleavages is not deterministically a consequence of the general integration of societies, but also the product of the action of parties and of their inherently competitive strategies" [6]. An area for future exploration would be to investigate the role of party organization over time with time-series data.

Finally, it would also be interesting to extend this research outside of Europe where comparable party organization data is available. Two issues should be considered here. First, we think that our theory on party organization and party strategy best fits countries in which voter-party linkages are mostly programmatic. Part of our argument for example assumes that parties appeal to voters (and voters consider voting for parties) based on ideological platforms. More specifically we posit that the extent to which ideological commitments made by parties are heterogeneous or homogeneous has important consequences for whether voters will support these parties across the territory. We are thus thinking about a world in which parties' electoral strategies are programmatic, which means that our argument would travel well to a series of other advanced industrial democracies such as Canada, Japan, Australia and the United States.

However, we are less certain that our hypotheses would hold in more clientelistic settings (i.e. India and Latin America) in which parties tend to have very different electoral strategies and where voters expect very different things from parties. ${ }^{32}$ In these contexts, other aspects of party strategy and party organization might be relevant to nationalization. Second, the European context in which we focus does not have much variation on certain institutional variables (namely electoral systems and regime type), so extending the analysis outside of this set of cases would allow to see whether the theory holds across a greater variety of institutional settings. We believe that it should hold, but it might be the case that certain institutions (such as the presidency) could neutralize or diminish the role that party organizational and ideological strategy have in determining nationalization. Alternatively a strong president could contribute to more leadership factionalism because of in-

\footnotetext{
${ }^{32}$ Recent literature Ziegfeld (2016) suggests that the dynamics of regionalization of party systems can be very different in clientelistic settings than in programmatic ones.
} 
ternal party competition generated by presidential elections. These are issues for further research. 


\section{References}

Aldrich, John H. 1995. Why Parties? The Origin and Transformation of Political Parties in America. University of Chicago Press.

Alesina, Alberto, Arnaud Devleeschauwer, William Easterly and Sergio Kurlat. 2003. "Fractionalization." Journal of Economic Growth 8(2):155-194.

Alesina, Alberto and Ekaterina Zhuravskaya. 2011. "Segregation and the quality of government in a cross-section of countries." American Economic Review 5(101):1872-1911.

Amorim Neto, Octavio and Gary W. Cox. 1997. "Electoral Institutions, Cleavage Structures, and the Number of Parties." American Journal of Political Science 41(1):149-174.

Bakke, Kristin and Erik Wibbels. 2006. "Diversity, Disparity, and Civil Conflict in Federal States." World Politics (59):1-50.

Bakker, Ryan, Catherine de Vries, Erica Edwards, Liesbet Hooghe, Seth Jolly, Gary Marks, Jonathan Polk, Jan Rovny, Marco Steenbergen and Milada Vachudova. 2012. "Measuring Party Positions in Europe: The Chapel Hill Expert Survey Trend File, 1999-2010." Party Politics pp. 1-15.

Bardi, Luciano, Stefano Bartolini and Alexander H. Trechsel. 2014. "Responsive and Responsible? The role of parties in twenty-First Century Politics." West European Politics 37(2):235-252.

Beck, Thorsten, George Clarke, Alberto Groff, Philip Keefer and Patrick Walsh. 2001. "New Tools in Comparative Political Economy: The Database of Political Institutions." World Bank Economic Review pp. 165-176.

Benoit, Kenneth and Michael Laver. 2007. "Estimating party policy positions: Comparing expert surveys and hand-coded content analysis." Electoral Studies 26:235-252.

Berry, William D., Matt Golder and Daniel Milton. 2012. "Improving Tests of Theories Positing Interaction." The Journal of Politics 74:653-671.

Bochsler, Daniel. 2010. "Measuring party nationalisation: A new Gini-based indicator that corrects for the number of units." Electoral Studies 29:155-168. 
Boucek, Francoise. 2003. "Managing Factional Conflict under Severe Constraints: John Major and British Conservatives 1992-97." Paper presented at the PSA 2003 Annual Conference in Leicester.

Boucek, Francoise. 2012. Factional Politics: How Dominant Parties Implode or Stabilize. London: Palgrave Macmillan.

Brambor, Thomas, William Roberts Clark and Matt Golder. 2006. "Understanding Interaction Models: Improving Empirical Analyses." Political Analysis 14:63-82.

Brancati, Dawn. 2009. Peace by Design: Managing Intrastate Conflict through Decentralization. Oxford University Press.

Caramani, Daniele. 2004. The Nationalization of Politics: The Formation of National Electorates and Party Systems in Western Europe. Cambridge University Press.

Carey, John and Matthew S. Shugart. 1995. "Incentives to Cultivate a Personal Vote." Electoral Studies 14(4):417-39.

Ceron, Andrea. 2015. "The Politics of Fission: Analysis of Faction Breakaways among Italian Parties (1946-2011)." British Journal of Political Science (2):121139.

Chandra, Kanchan. 2004. Why Ethnic Parties Succeed: Patronage and Ethnic Head Counts in India. Cambridge University Press.

Chhibber, Pradeep K. and Kenneth Kollman. 1998. "Party Aggregation and the Number of Parties in India and the United States." American Political Science Review 92(2):329-342.

Chhibber, Pradeep K. and Kenneth Kollman. 2004. The Formation of National Party Systems: Federalism and Party Competition in Canada, Great Britain, India and the United States. Princeton University Press.

Chhibber, Pradeep K. and Pavithra Suryanarayan. 2014. "Party Organization and party proliferation in India." Party Politics 20(4):489-505.

Clark, William Roberts and Matt Golder. 2006. "Rehabilitating Duverger's Theory: Testing the Mechanical and Strategic Modifying Effects of Electoral Laws." Comparative Political Studies 39(6):679-708. 
Cox, Gary and Jonathan S. Knoll. 2003. "Ethnes, Fiscs, and Electoral Rules: The Determinants of Party-System Inflation.".

Cox, Gary W. and Mathew D. McCubbins. 1999. "Electoral Rules and Electoral Coordination." Annual Review of Political Science (2):145-161.

Cox, Gary W. and McCubbins. 2005. Setting the Agenda Responsible Party Government in the U.S. House of Representatives. Cambridge University Press.

Czaniawska-Joerges, Barbara. 1988. Ideological Control in Nonideological Organizations. New York: Praeger.

Duverger, Maurice. 1954. Political Parties Their Organization and Activity in the Modern State.

Forestiere, Carolyn. 2009. "Kirchheimer Italian Style: Catch-All Parties or CatchAll Blocs." Party Politics (15):573-591.

Gelman, Andrew and Jenniffer Hill. 2006. Data Analysis Using Regression and Multilevel/Hierarchical Models. Cambridge University Press.

Golosov, Grigorii V. 2016. "Factors of party nationalization." International Political Science Review 37(2):246-260.

Greene, Zachary and Matthias Haber. 2015. "Leadership Competition and Disagreement at Party National Congresses." British Journal of Political Science (2):1-22.

Hale Williams, Michelle. 1009. "Kirchheimers French Twist. A model of the Catchall Thesis applied to the French Case." Party Politics 15(5):592-614.

Harmel, Robert. 2002. Party Organizational Change: Competing Explanations? In Political Parties in the New Europe: Political and Analytical Challenges, ed. Kurt Richard Luther and Ferdinand Muller Rommel. Oxford University Press.

Hatch, Mary Jo. 1997. Organization Theory. Oxford University Press.

Hazan, Reuven Y. 2002. Candidate Selection. In Comparing Democracies. Elections and Voting in Global Perspective, ed. Pippa Norris Lawrence LeDuc, Richard G. Niemi. London: Sage Publications.

Hicken, Allen. 2009. Building Party Systems in Developing Democracies. Cambridge University Press. 
Hicken, Allen and Heather Stoll. 2013. "Are All Presidents Created Equal? Presidential Powers and the Shadow of Presidential Elections." Comparative Political Studies 46(3).

Hooghe, Liesbet, Gary Marks, Arjan H. Schakel, Sandi Chapman Osterkatz, Sara Niedzwiecki and Sarah Shair-Rosenfield. 2015. A Postfunctionalist Theory of Governance. Oxford: Oxford University Press.

Ishiyama, John T. 2001. "Party Organization and the Political Success of the Communist Successor Parties." Social Science Quarterly 82(4):844-864.

Janda, Kenneth. 1980. Political Parties. A Cross-National Survey. New York: Free Press.

Janda, Kenneth and Desmond S. King. 1985. "Formalizing and Testing Duverger's Theories on Political Parties." Comparative Political Studies 18:139-169.

Janda, Kenneth and Tyler Colman. 1998. "Effects of Party Organization on Performance during the 'Golden Age' of Parties." Political Studies 46:611-632.

Jones, Mark P. and Scott Mainwaring. 2003. "The Nationalization of Parties and Party Systems: An Empirical Measure and an Application to the Americas." Party Politics 9(2):139166.

Katz, R. S. 1980. A Theory of Parties and Electoral Systems. Baltimore and London: The Johns Hopkins University Press.

Kernell, Georgia. 2013. Political Party Organizations, Civic Representation, and Participation. In Representation: Elections and Beyond, ed. Jack Nagel and Rogers Smith. Pennsylvania: University of Pennsylvania Press.

Kirchheimer, Otto. 1966. The Transformation of the West European Party Systems. In Political Parties and Political Development, ed. Joseph LaPalombara and Myron Weiner. New Jersey: Princeton University Press.

Kirchheimer, Otto. 2008. "The Transformation of European Party Systems." Paper prepared for the Conference of Political Parties and Political Development, Villa Falcxonieri, Frascati, Italy. 6-9January, 83.1, Kirchheimer Papers, University of Albany.

Kitschelt, H., Z. Mansfeldova, R. Markowski and G. Tka. 1999. Postcommunist Party Systems. Competition. Representation and Inter-Party Cooperation. Cambridge: Cambridge University Press. 
Leon, Sandra. 2014. "How does decentralization affect electoral competition of state-wide parties? Evidence from Spain." Party Politics 20(3):391402.

Lipset, Seymour M. and Stein Rokkan. 1967. Party Systems and Voters Alignments: Cross-National Perspectives. Free Press.

Lublin, David. 2015. "Minority Rules Dataset [data file and codebook].".

Mair, Peter. 2013. Ruling the Void: The Hollowing of Western Democracy. London: Verso.

McAllister, I. 1991. "Party Adaptation and Factionalism within the Australian Party System." American Journal of Political Science 35:206-227.

McGann, A. J. 2002. "The Advantages of Ideological Cohesion: A Model of Constituency Representation and Electoral Competition in Multi-Party Democracies." Journal of Theoretical Politics 14:37-70.

Meguid, Bonnie. 2008. "Institutional Change as Strategy: The Role of Decentralization in Party Competition." Annual Meeting of the American Political Science Association.

Mintzberg, Henry. 1990. The Design School: Reconsidering the Basic Premises of Strategic Management. John Wiley and Sons Limited.

Morgenstern, Scott, Stephen M. Swindle and Andrea Castagnola. 2009. "Party Nationalization and Institutions." The Journal of Politics 71(4):1322-1341.

Mylonas, Harris and Nasos Roussias. n.d. "Does Party Structure affect Electoral Success? Center-Right Party Organization in Europe." Annual Meeting of the American Political Science Association.

Norris, Pippa. 1996. Legislative Recruitment. In Comparing Democracies. Elections and Voting in Global Perspective, ed. Pippa Norris Lawrence LeDuc, Richard G. Niemi. London: Sage Publications.

Rabe-Hesketh, Sophia and Anders Skrondal. 2012. Multilevel and Longitudinal Modeling Using Stata. Stata Press.

Rahat, Gideon. 2009. "Which Candidate Selection Method is the Most Democratic?" Government and Opposition 44(1):6890. 
Rahat, Gideon, Hazan Reuven and Richard Katz. 2008. "Democracy and political parties. On the uneasy relationships between participation, competition and representation." Party Politics 14(6):663-683.

Rahat, Gideon and Reuven Y. Hazan. 2001. "Candidate Selection Methods: An Analytical Framework." Party Politics 7:297-322.

Rodden, Jonathan. 2010. Federalism and Inter-Regional Redistribution. In The Political Economy of Inter-Regional Flows, ed. Marta Espasa Albert Sole Olle Bosch, Nuria. Edward Elgar.

Rose, Richard and Derek W. Urwin. 1975. Regional Differentiation and Political Unity in Western Nations. Sage Publications.

Sartori, Giovanni. 1976. Parties and Party Systems: A Framework for Analysis. Cambridge, Cambridge University Press.

Scarrow, Susan E. 1994. "The 'paradox of enrollment': Assessing the costs and benefits of party memberships." European Journal of Political Research (1):4160.

Scarrow, Susan E and Paul D. Webb. 2013. "Assessing Party Organizational Change: Participation, Representation and Power." Paper prepared for presentation at the American Political Science Association Annual Meetings, Chicago, IL August 29-September 1.

Schattschneider, E. E. 1942. Party Government. New York: Rinehart and Company.

Schumacher, Gijs, Catherine de Vries and Barbara Vis. 2013. "Why Do Parties Change Position? Party Organization and Environmental Conditions." The Journal of Politics (75):464-477.

Selway, Joel Sawat. 2011. "The Measurement of Cross-cutting Cleavages and Other Multidmensional Cleavage Structures." Political Analysis 19:48-65.

Snyder, James M. and Michael M. Ting. 2002. "An Informational Rationale for Political Parties." American Journal of Political Science 46(1):90-110.

Strom, Kaare. 1990. "A Behavioral Theory of Competitive Political Parties." American Journal of Political Science 34(2):565-598. 
Tavits, Margit. 2011. "Organizing for Success: Party Organizational Strength and Electoral Performance in Postcommunist Europe." Journal of Politics 74(1):8397.

Tsebelis, George. 2002. Veto Players: How Political Institutions Work. Princeton University Press.

Ziegfeld, Adam. 2016. Why Regional Parties? Clientelism, Elites, and the Indian Party System. Cambridge University Press. 


\section{Online appendix: Tables and Figures}

Table 4: Countries and Political Parties

\begin{tabular}{|c|c|}
\hline Country & Party Name \\
\hline \multirow[t]{5}{*}{ Austria } & SPO (Social Democratic Party of Austria) \\
\hline & VP (Austrian Peoples Party) \\
\hline & GRUNE (The Greens) \\
\hline & FP (Freedom Party of Austria) \\
\hline & BZ (Alliance for the Future of Austria) \\
\hline \multirow[t]{8}{*}{ Belgium } & VLD (Flemish Liberal and Democrats) \\
\hline & SPA (Socialist Party.Different) \\
\hline & SPIRIT (The Flemish Left Liberals) \\
\hline & CD\&V (Christian-Democratic and Flemish) \\
\hline & N-VA (New Flemish Alliance) \\
\hline & PS (Socialist Party) \\
\hline & VB (Flemish Interest) \\
\hline & MR (Reform Movement) \\
\hline \multirow[t]{9}{*}{ Czech Republic } & ODS (Civic Democratic Party) \\
\hline & SSD (Czech Social Democratic Party) \\
\hline & KSM (Communist Party of Bohemia and Moravia) \\
\hline & KDU-SL (Christian and Democratic Union) \\
\hline & SZ (Green Party) \\
\hline & ODA \\
\hline & CDH (Humanist Democratic Centre) \\
\hline & ECOLO (Ecologists) \\
\hline & FN (National Front) \\
\hline \multirow[t]{6}{*}{ Germany } & SPD (Social Democratic Party) \\
\hline & CDU (Christian Democratic Union) \\
\hline & FDP (Free Democratic Party) \\
\hline & Die Linke.PDS (The Left Party.PDS) \\
\hline & Bndnis 90/GRNE (Alliance 90/The Greens) \\
\hline & CSU (Christian Social Union in Bavaria) \\
\hline \multirow[t]{4}{*}{ Denmark } & V (Venstre, Liberal Party) \\
\hline & SD (Social Democracy) \\
\hline & DF (Danish People's Party) \\
\hline & KF (Conservative People's Party) \\
\hline
\end{tabular}

Continued 


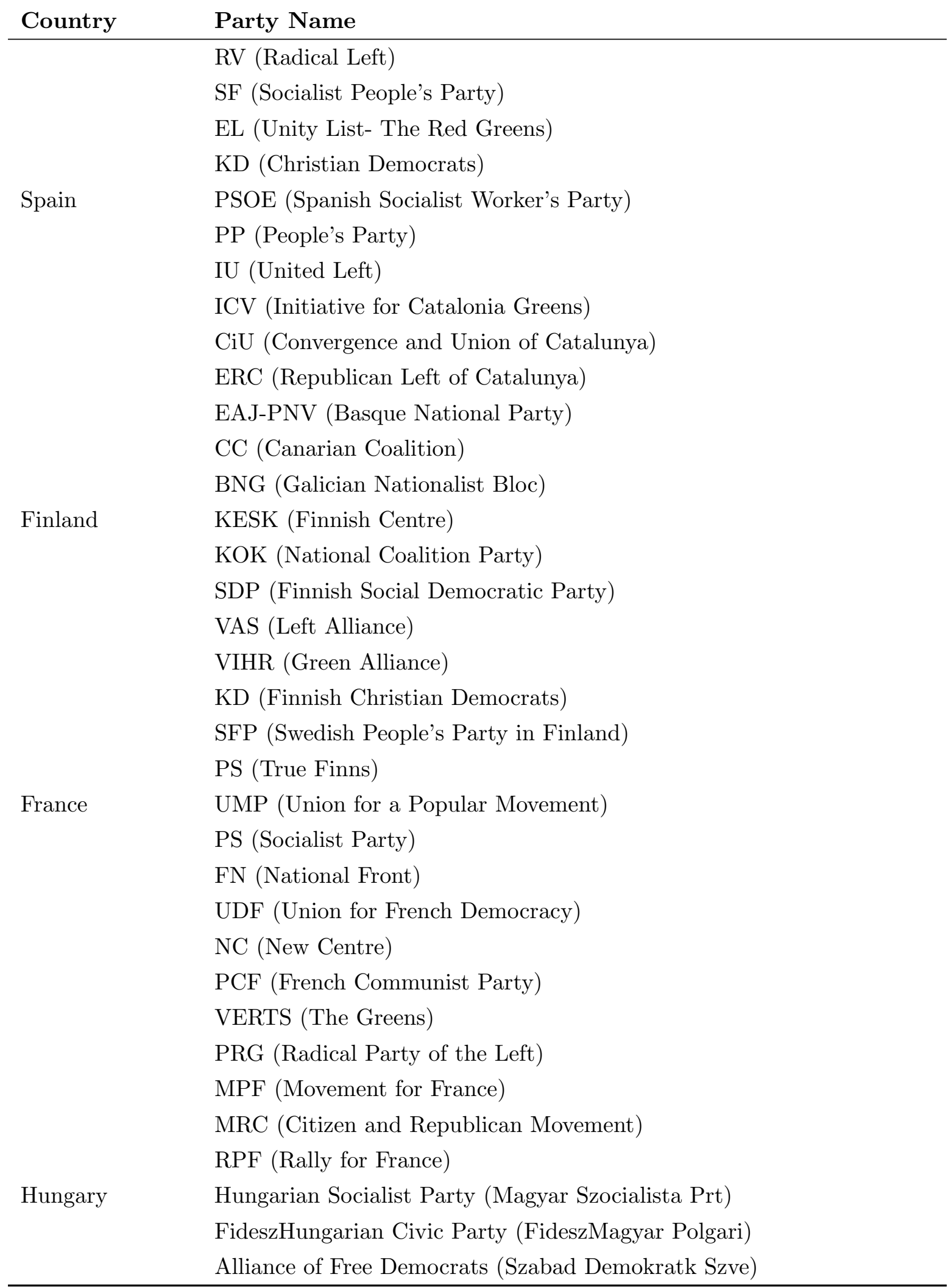

Continued 


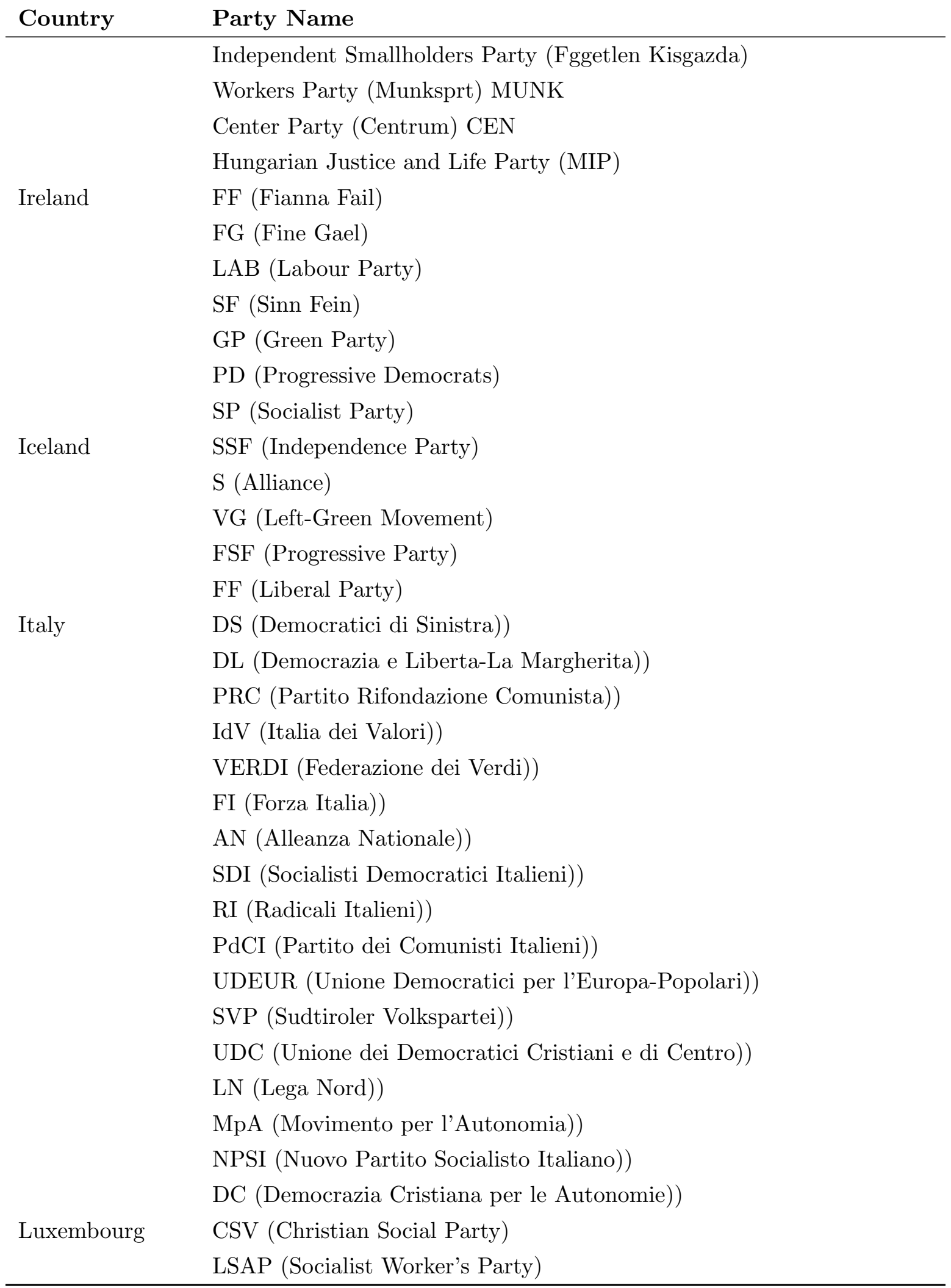

Continued 


\begin{tabular}{|c|c|}
\hline Country & Party Name \\
\hline \multirow{7}{*}{ Norway } & DP (Democratic Party) \\
\hline & GRENG (The Greens) \\
\hline & ADR (Alternativ Democratic Reform Party) \\
\hline & A (Norwegian Labour Party) \\
\hline & FRP (Progress Party) \\
\hline & H (Right) \\
\hline & SV (Socialist Left Party) \\
\hline \multirow{7}{*}{ Poland } & KRF (Christian People's Party) \\
\hline & SP (Centre Party) \\
\hline & V (Venstre-Left) \\
\hline & PiS (Law and Justice) \\
\hline & PO (Civic Platform) \\
\hline & SRP (Self-Defence of the Republic of Poland) \\
\hline & SLD (Democratic Left Alliance) \\
\hline \multirow{7}{*}{ Portugal } & UP (Labour Union) \\
\hline & LPR (League of Polish Families) \\
\hline & PSL (Polish People's Party) \\
\hline & PS (Socialist Party) \\
\hline & PSD (Social Democratic Party) \\
\hline & PCP (Portuguese Communist Party) \\
\hline & PEV (Ecological Party The Greens) \\
\hline \multirow{5}{*}{ Romania } & CDS-PP (Democratic Social Centre) \\
\hline & BE (Left Bloc) \\
\hline & PSD (Social Democratic Party) \\
\hline & PC (Conservative Party) \\
\hline & PNL (National Liberal Party) \\
\hline \multirow{9}{*}{ Sweden } & PD (Democratic Party) \\
\hline & PRM (Great Romania Party) \\
\hline & PUNR \\
\hline & UDMR (Democratic Alliance of Hungarians in Romania) \\
\hline & SAP (Social Democratic Workers' Party) \\
\hline & M (Moderate Rally Party) \\
\hline & C (Centre Party) \\
\hline & FP (Liberal People's Party) \\
\hline & KD (Christian Democrats) \\
\hline
\end{tabular}

Continued 


\begin{tabular}{ll} 
Country & Party Name \\
\hline VP (Left Party) & MP (Environment Party The Greens) \\
Switzerland & SVP (Swiss People's Party) \\
& SP (Social Democratic Party of Switzerland) \\
& FDP (Freethinking Democratic Party) \\
& CVP (Christian Democratic People's Party) \\
& GPS (Green Party of Switzerland) \\
& EVP (Evangelical People's Party) \\
& LPS (Liberal Party of Switzerland) \\
& EDU (Federal Democratic Union) \\
& PdA (Labour Party) \\
LAB (Labour Party) \\
CON (Conservative Party) \\
LD (Liberal Democrats) \\
SNP (Scottish National Party) \\
DUP (Democratic Unionist Party) \\
PC (Playd Cymru) \\
SF (Sinn Fein) \\
SDLP (Social Democratic and Labour Party) \\
UUP
\end{tabular}


Table 5: Information and Sources for Dependent Variable

\begin{tabular}{lclc}
\multicolumn{1}{c}{ Country } & Data Collected & Source & Districts \\
\hline Austria & 2008 & Elections Resources & 9 \\
Belgium & 2010 & EED ${ }^{34}$ Nuts 3 & 11 \\
Czech Republic & 2010 & EED - Nuts 3 & 14 \\
Denmark & 2011 & EED & 10 \\
Finland & 2011 & EED & 15 \\
France & 2012 & Ministry of Interior, France & 565 \\
Germany & 2009 & EED & 16 \\
Hungary & 2010 and 2006 & EED - Nuts 3 & 20 \\
Iceland & 2009 & EED - Constituency & 6 \\
Ireland & 2011 and 2007 & EED - Constituency & 43 \\
Italy & 2008 & EED - Districts & 27 \\
Luxembourg & 2009 & Election Resources & 4 \\
Norway & 2009 & EED - Nuts 3 & 19 \\
Poland & 2011 & EED - Constituency & 41 \\
Portugal & 2009 & EED - Districts & 20 \\
Romania & 2008 & EED - Nuts 3 & 42 \\
Spain & 2008 & EED - Nuts 3 & 52 \\
Sweden & 2010 & EED - Nuts 3 \& Elections Resources & 29 \\
Switzerland & 2011 & EED - Nuts 3 & 26 \\
UK & 2010 & Electoral Commission UK & 650 \\
\hline
\end{tabular}


Table 6: Summary statistics

\begin{tabular}{lccccc}
\hline \multicolumn{1}{c}{ Variable } & Mean & Std. Dev. & Min. & Max. & N \\
\hline Party Nationalization & 0.697 & 0.267 & 0.046 & 0.950 & 145 \\
Ideological Unity & 3.776 & 0.609 & 2 & 4.8 & 150 \\
Leadership Factionalism & 2.371 & 0.736 & 1 & 4.600 & 154 \\
Party Centralization & 3.613 & 0.631 & 2 & 5 & 152 \\
Concentration of Diversity (log) & -1.856 & 0.307 & -2.348 & -1.127 & 157 \\
Political Decentralization & 3.048 & 1.559 & 0 & 5.749 & 157 \\
Average District Magnitude (log) (DPI) & 1.974 & 1.039 & 0 & 3.114 & 157 \\
Number of Electoral Districts (log) & 3.416 & 1.291 & 1.386 & 6.477 & 157 \\
Party Age & 44.058 & 39.474 & 0 & 175 & 154 \\
Regionalist Party & 0.083 & 0.276 & 0 & 1 & 157 \\
New Democracy (dic) & 0.732 & 0.444 & 0 & 1 & 157 \\
\hline
\end{tabular}

Table 7: Wording of Questions in Party unity Expert Survey in Europe

\begin{tabular}{l|l} 
Variables & Questions \\
\hline Leadership factionalism & $\begin{array}{l}\text { Some parties have "factions," defined as intra-party } \\
\text { groups organized to act collectively as distinct blocs } \\
\text { within the party. Factions may pursue various objec- } \\
\text { tives. Please rate each party as of 2006/2007 for the } \\
\text { extent of factionalism based on the personal attraction } \\
\text { of individual leaders. } \\
\text { 1-none 2- little 3- some 4- a lot 5- a great deal }\end{array}$ \\
\hline Ideological unity & $\begin{array}{l}\text { On a scale from 1 to 5 please assign a score for each party } \\
\text { regarding its ideological unity (party programmatic co- } \\
\text { hesion) for the } 2006 / 2007 \text { period. }\end{array}$ \\
& $\begin{array}{l}\text { 1-50\% or less agreement 2 - Over } 60 \% 3 \text { - Over } 70 \% 4 \\
\text { - Over 80\% 5 - Over 90\% agreement }\end{array}$ \\
\hline Centralization & $\begin{array}{l}\text { Centralization of power refers to the location and distri- } \\
\text { bution of effective decision-making authority within the } \\
\text { party with regard to the top national party organs. As- } \\
\text { sign a score from 1 to 5 to each party for the level of cen- } \\
\text { tralization in decision-making, selection of candidates, } \\
\text { and the distribution of party finances as of } 2006 / 2007 . \\
\text { 1- very low 2- low 3- medium 4- high 5- very high }\end{array}$ \\
\hline
\end{tabular}


Figure 6: Interaction ideological unity and decentralization
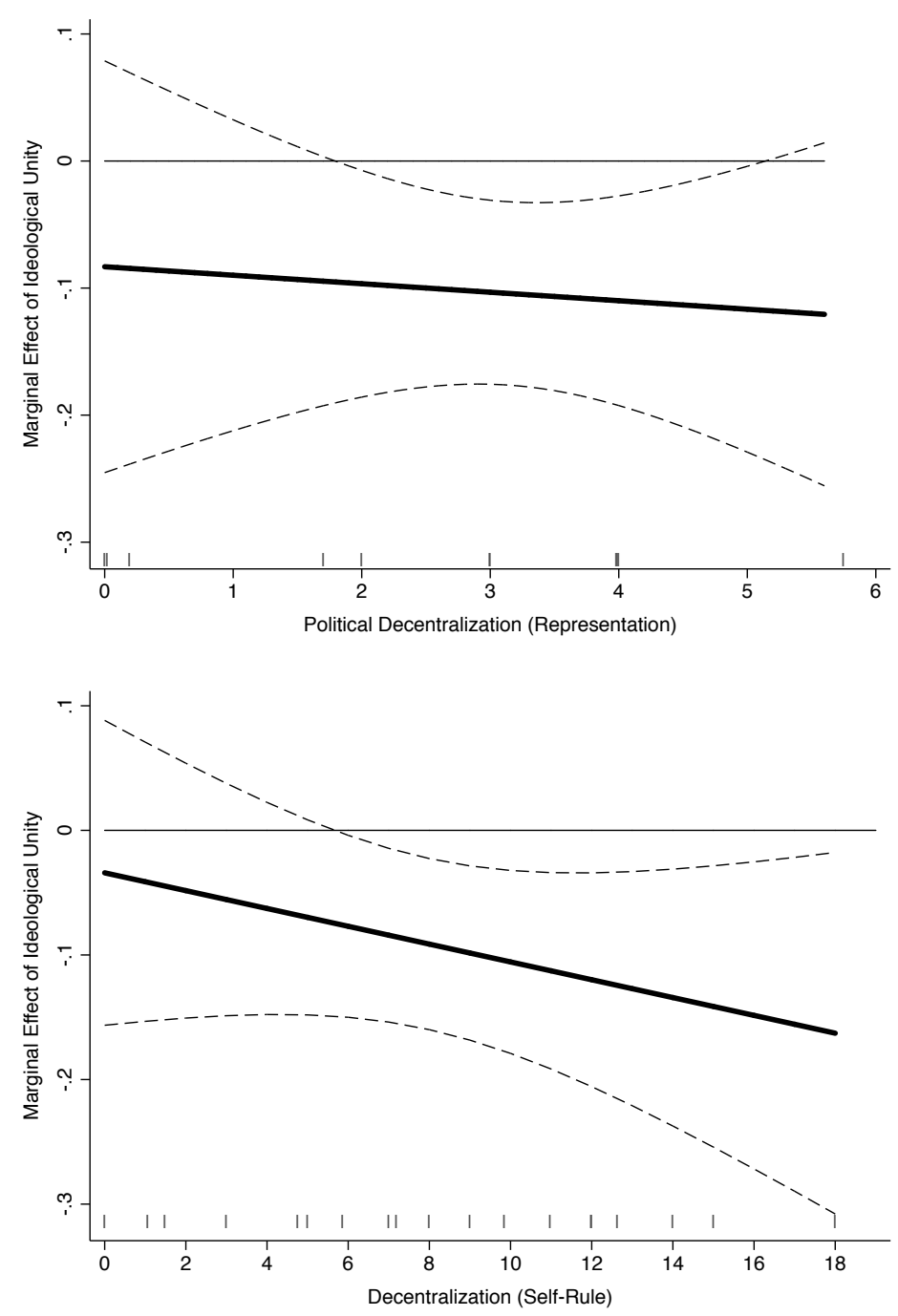
Figure 7: Robustness using alternative measures of geographic concentration of diversity
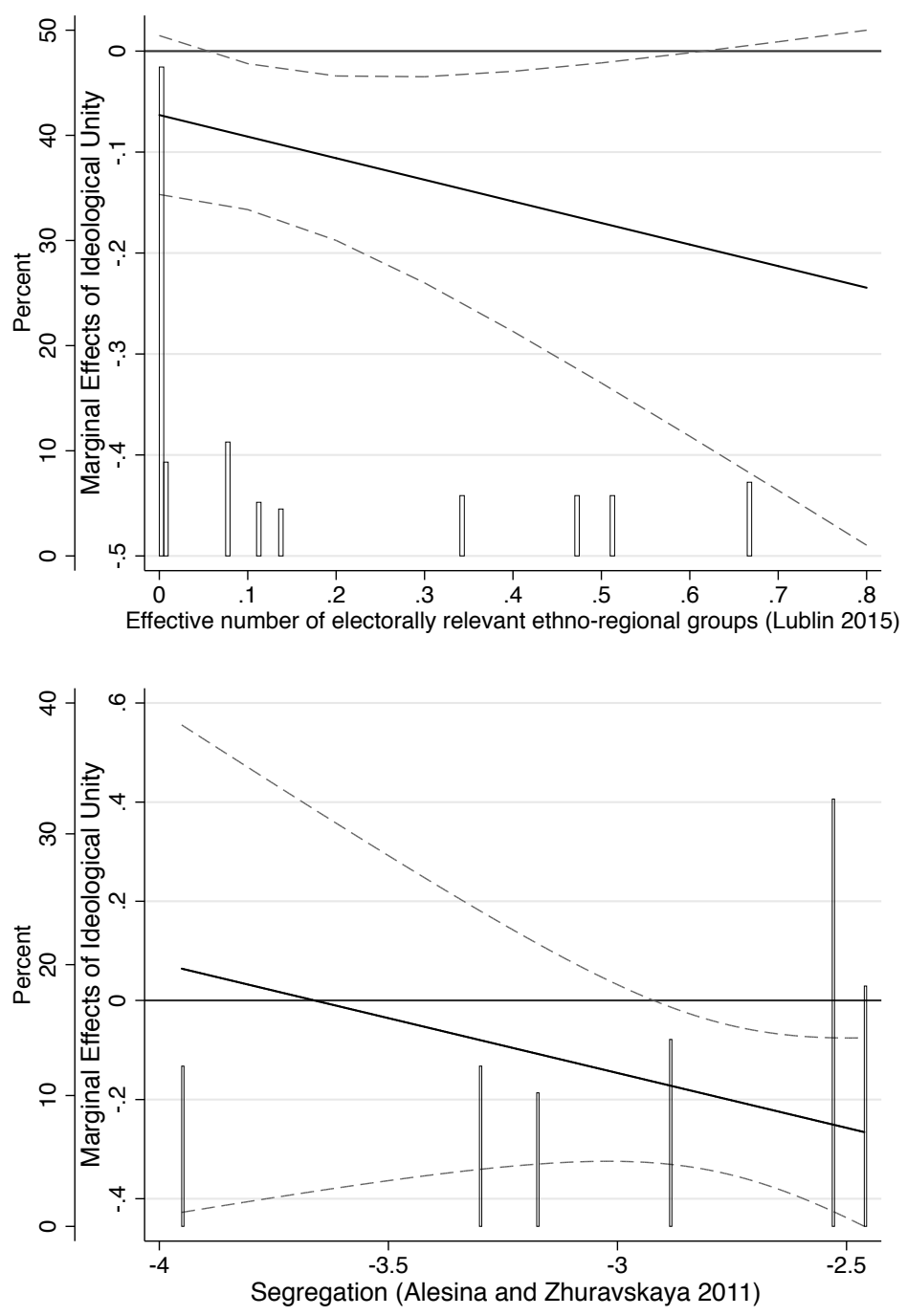
Table 8: Cross-level interactions with territorial coverage as dependent variable

\begin{tabular}{|c|c|c|c|c|}
\hline Dependent Variable: Territorial Coverage & M1 & M2 & M3 & M4 \\
\hline Ideological Unity & $\begin{array}{c}-.140^{* * *} \\
(.05)\end{array}$ & $\begin{array}{c}-.335^{* * *} \\
(.10)\end{array}$ & $\begin{array}{c}-.033 \\
(.11)\end{array}$ & $\begin{array}{c}-.550^{* *} \\
(.23)\end{array}$ \\
\hline Leadership Factionalism & $\begin{array}{l}.049 \\
(.07)\end{array}$ & $\begin{array}{c}-.071^{*} \\
(.04)\end{array}$ & $\begin{array}{c}-.081^{* *} \\
(.04)\end{array}$ & $\begin{array}{c}-.061^{*} \\
(.04)\end{array}$ \\
\hline Party Centralization & $\begin{array}{l}.022 \\
(.04)\end{array}$ & $\begin{array}{l}.025 \\
(.04)\end{array}$ & $\begin{array}{l}.035 \\
(.04)\end{array}$ & $\begin{array}{l}.021 \\
(.04)\end{array}$ \\
\hline Political Decentralization & $\begin{array}{l}.040 \\
(.05)\end{array}$ & $\begin{array}{c}-.047^{*} \\
(.03)\end{array}$ & $\begin{array}{c}-.035^{*} \\
(.02)\end{array}$ & $\begin{array}{c}-.039 \\
(.03)\end{array}$ \\
\hline Average District Magnitude (log) & $\begin{array}{c}.090^{* *} \\
(.04)\end{array}$ & $\begin{array}{r}-.247 \\
(.16)\end{array}$ & & $\begin{array}{l}.086^{*} \\
(.04)\end{array}$ \\
\hline Number of Electoral Districts (log) & & & $\begin{array}{l}.022 \\
(.12)\end{array}$ & \\
\hline Concentration of Diversity (log) & $\begin{array}{c}-.058 \\
(.14)\end{array}$ & $\begin{array}{c}-.041 \\
(.14)\end{array}$ & $\begin{array}{c}-.062 \\
(.10)\end{array}$ & $\begin{array}{l}.832 \\
(.52)\end{array}$ \\
\hline Leadership Factionalism $\times$ Political Decentralization & $\begin{array}{c}-.037^{* *} \\
(.02)\end{array}$ & & & \\
\hline Ideological Unity $\times$ Average District Magnitude (log) & & $\begin{array}{c}.093^{* *} \\
(.04)\end{array}$ & & \\
\hline Ideological Unity $\times$ Number of Electoral Districts $(\log )$ & & & $\begin{array}{c}-.032 \\
(.03)\end{array}$ & \\
\hline Ideological Unity $\times$ Concentration of Diversity $(\log )$ & & & & $\begin{array}{c}-.229^{*} \\
(.13)\end{array}$ \\
\hline Regionalist Party & $\begin{array}{c}-.429^{* * *} \\
(.08)\end{array}$ & $\begin{array}{c}-.411^{* * *} \\
(.08)\end{array}$ & $\begin{array}{c}-.402^{* * *} \\
(.08)\end{array}$ & $\begin{array}{c}-.430^{* * *} \\
(.08)\end{array}$ \\
\hline Party Age & $\begin{array}{l}.000 \\
(.00)\end{array}$ & $\begin{array}{l}.000 \\
(.00)\end{array}$ & $\begin{array}{l}.000 \\
(.00)\end{array}$ & $\begin{array}{l}.000 \\
(.00)\end{array}$ \\
\hline New Democracy (dic) & $\begin{array}{r}-.047 \\
(.09)\end{array}$ & $\begin{array}{c}-.032 \\
(.09)\end{array}$ & $\begin{array}{r}-.052 \\
(.07)\end{array}$ & $\begin{array}{c}-.013 \\
(.10)\end{array}$ \\
\hline Constant & $\begin{array}{c}1.060^{* *} \\
(.43)\end{array}$ & $\begin{array}{c}2.049^{* * *} \\
(.53)\end{array}$ & $\begin{array}{c}1.366^{* * *} \\
(.51)\end{array}$ & $\begin{array}{c}2.891^{* * *} \\
(.97)\end{array}$ \\
\hline No. of cases & 142 & 142 & 142 & 142 \\
\hline No. of countries & 20 & 20 & 20 & 20 \\
\hline
\end{tabular}

Sig: ${ }^{*} p<0.10,{ }^{* *} p<0.05,{ }^{* * *} p<0.01$ 
Table 9: Models without regional parties (M1) and controlling for regional parties (M2)

\begin{tabular}{lcc} 
Dependent Variable: Party Nationalization & $\mathrm{M} 1$ & $\mathrm{M} 2$ \\
\hline Ideological Unity & $-.130^{* * *}$ & $-.129^{* * *}$ \\
& $(.04)$ & $(.04)$ \\
Leadership Factionalism & .039 & $-.079^{* *}$ \\
& $(.03)$ & $(.03)$ \\
Party Centralization & .035 & .050 \\
& $(.03)$ & $(.04)$ \\
Party Age & .001 & .000 \\
& $(.00)$ & $(.00)$ \\
Concentration of Diversity $(\log )$ & -.099 & $-.155^{*}$ \\
& $(.10)$ & $(.08)$ \\
Political Decentralization & $-.032^{*}$ & $-.029^{*}$ \\
& $(.02)$ & $(.01)$ \\
Average District Magnitude $(\log )(\mathrm{DPI})$ & .040 & .030 \\
& $(.03)$ & $(.03)$ \\
New Democracy (dic) & -.071 & .008 \\
& $(.07)$ & $(.06)$ \\
Countries with Regional Parties & & -.057 \\
& & $(.05)$ \\
Constant & $1.044^{* * *}$ & $.945^{* * *}$ \\
& $(.32)$ & $(.29)$ \\
\hline No. of parties & 129 & 142 \\
No. of countries & 20 & 20 \\
\hline Sig: ${ }^{*} p<0.10,{ }^{* *} p<0.05,{ }^{* * *} p<0.01$ & &
\end{tabular}


Table 10: Cross-level interactions without regional parties

\begin{tabular}{|c|c|c|c|c|}
\hline & M1 & M2 & M3 & M4 \\
\hline Ideological Unity & $\begin{array}{c}-.131^{* * *} \\
(.04)\end{array}$ & $\begin{array}{c}-.286^{* * *} \\
(.09)\end{array}$ & $\begin{array}{l}.006 \\
(.10)\end{array}$ & $\begin{array}{c}-.393^{* *} \\
(.19)\end{array}$ \\
\hline Leadership Factionalism & $\begin{array}{l}.054 \\
(.06)\end{array}$ & $\begin{array}{c}-.046 \\
(.03)\end{array}$ & $\begin{array}{l}-.047 \\
(.03)\end{array}$ & $\begin{array}{l}-.037 \\
(.03)\end{array}$ \\
\hline Party Centralization & $\begin{array}{l}.037 \\
(.03)\end{array}$ & $\begin{array}{l}.041 \\
(.03)\end{array}$ & $\begin{array}{l}.042 \\
(.03)\end{array}$ & $\begin{array}{l}.037 \\
(.03)\end{array}$ \\
\hline Political Decentralization & $\begin{array}{l}.040 \\
(.04)\end{array}$ & $\begin{array}{c}-.033^{*} \\
(.02)\end{array}$ & $\begin{array}{r}-.026 \\
(.02)\end{array}$ & $\begin{array}{r}-.029 \\
(.02)\end{array}$ \\
\hline Concentration of Diversity (log) & $\begin{array}{l}-.092 \\
(.10)\end{array}$ & $\begin{array}{c}-.079 \\
(.10)\end{array}$ & $\begin{array}{l}-.095 \\
(.10)\end{array}$ & $\begin{array}{l}.471 \\
(.43)\end{array}$ \\
\hline Average District Magnitude (log) (DPI) & $\begin{array}{l}.043 \\
(.03)\end{array}$ & $\begin{array}{l}-.220^{*} \\
(.13)\end{array}$ & & $\begin{array}{l}.040 \\
(.03)\end{array}$ \\
\hline Number of Electoral Districts (log) & & & $\begin{array}{l}.126 \\
(.11)\end{array}$ & \\
\hline Leadership Factionalism $\times$ Political Decentralization & $\begin{array}{c}-.031^{*} \\
(.02)\end{array}$ & & & \\
\hline Ideological Unity $\times$ Average District Magnitude $(\log )$ & & $\begin{array}{c}.073^{* *} \\
(.04)\end{array}$ & & \\
\hline Ideological Unity $\times$ Number of Electoral Districts $(\log )$ & & & $\begin{array}{c}-.043 \\
(.03)\end{array}$ & \\
\hline Ideological Unity $\times$ Concentration of Diversity $(\log )$ & & & & $\begin{array}{l}-.144 \\
(.10)\end{array}$ \\
\hline Party Age & $\begin{array}{l}.001 \\
(.00)\end{array}$ & $\begin{array}{l}.001 \\
(.00)\end{array}$ & $\begin{array}{l}.001 \\
(.00)\end{array}$ & $\begin{array}{l}.001 \\
(.00)\end{array}$ \\
\hline New Democracy (dic) & $\begin{array}{c}-.069 \\
(.07)\end{array}$ & $\begin{array}{l}-.061 \\
(.07)\end{array}$ & $\begin{array}{c}-.072 \\
(.07)\end{array}$ & $\begin{array}{l}-.050 \\
(.07)\end{array}$ \\
\hline Constant & $\begin{array}{c}.833^{* *} \\
(.34)\end{array}$ & $\begin{array}{c}1.627^{* * *} \\
(.42)\end{array}$ & $\begin{array}{l}.714 \\
(.47)\end{array}$ & $\begin{array}{c}2.052^{* *} \\
(.80)\end{array}$ \\
\hline No. of cases & 129 & 129 & 129 & 129 \\
\hline No. of countries & 20 & 20 & 20 & 20 \\
\hline
\end{tabular}

Sig: ${ }^{*} p<0.10,{ }^{* *} p<0.05,{ }^{* * *} p<0.01$ 
Figure 8: Marginal effects of cross-level interactions (sample without regional parties)
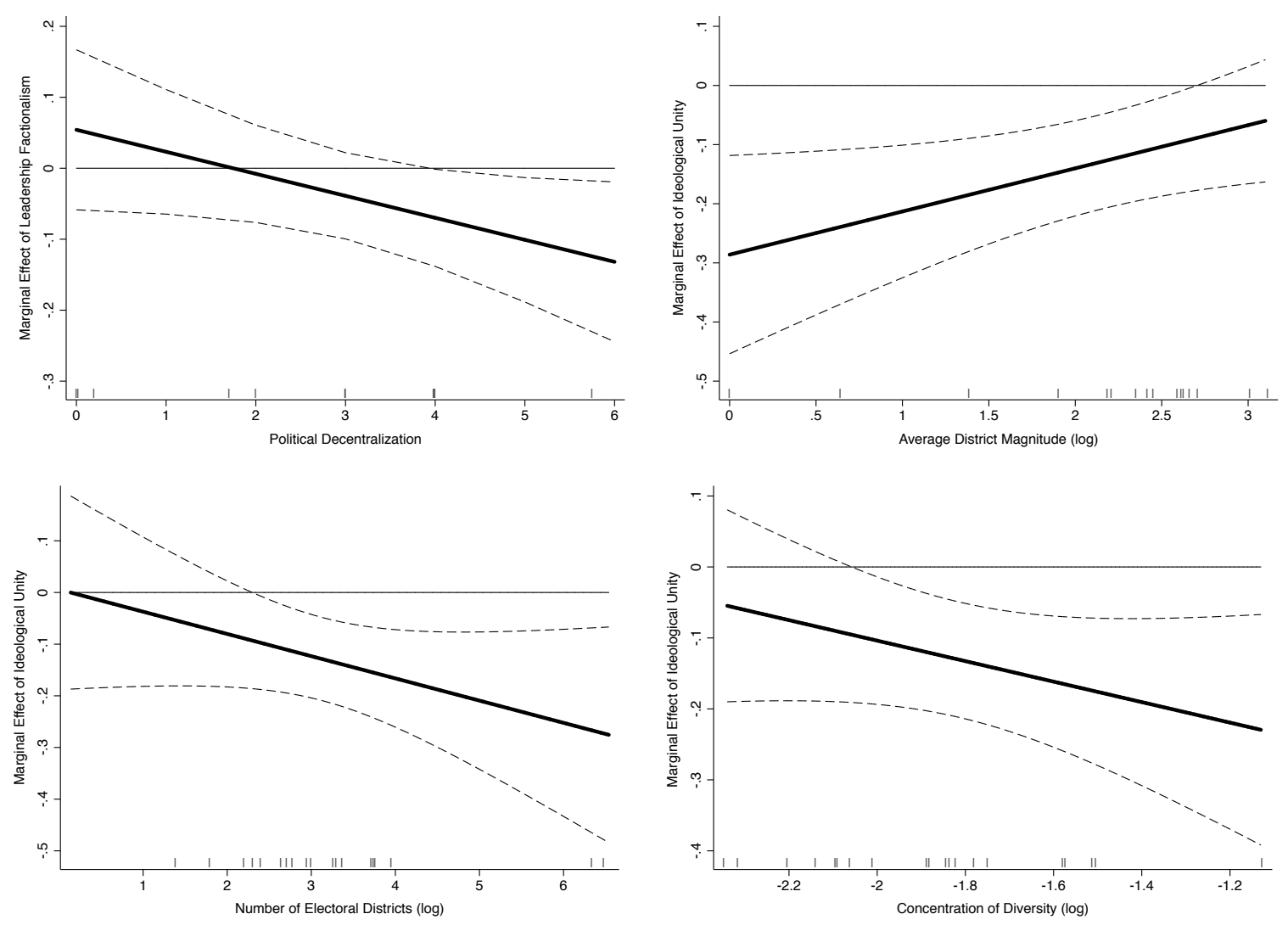